\title{
PTERIDOPHYTE FLORA OF LESVOS (EAST AEGEAN ISLANDS, GREECE)
}

\author{
I. BAZOS* \& A. YANNITSAROS*
}

\begin{abstract}
New data on the Pteridophyta of Lesvos (East Aegean Islands, Greece) contributing to the knowledge of their distribution and ecology are given. The presence of 24 taxa (species and subspecies) belonging to 16 genera and 7 families is confirmed whilst the occurrence of 4 more previously recorded is considered as doubtful or needs more recent confirmation. Isoetes duriei Bory, Pilularia minuta Durieu and Polystichum setiferum (Forsskål) Woynar appear to be new records for the East Aegean Islands, and Isoetes histrix Bory is new for the island of Lesvos. Furthermore the presence on Lesvos of some rare species (i.e. Notholaena marantae (L.) Desv. and Ophioglossum vulgatum L.) is confirmed. Critical comments on most of the taxa are made and dot maps of their distributions are presented. With regard to the rare species and their habitats, a need for urgent conservation measures is identified.
\end{abstract}

Keywords. Fern distribution, fern ecology, phytogeography, species protection.

\section{INTRODUCTION}

Lesvos is the largest East Aegean Island and the third largest of all the Greek islands following Kriti and Evvia. It has an area of $1630 \mathrm{~km}^{2}$ and extends between $25^{\circ} 50^{\prime} 02^{\prime \prime}$ and $26^{\circ} 37^{\prime} 03^{\prime \prime} \mathrm{E}$ longitudes and $38^{\circ} 57^{\prime} 39^{\prime \prime}$ and $39^{\circ} 23^{\prime} 23^{\prime \prime} \mathrm{N}$ latitudes. There are not particularly high mountains in Lesvos although the island is rather mountainous. Some of its highest mountains are: Olimbos (highest summit Profitis Ilias 968m), Lepetimnos (968m), Psilokoudouno (914m), Roditis (845m), Profitis Ilias (E of Pterounda, 799m), Petrovouni (755m), Skotino (699m), Routfas (673m), Oxia Petra $(566 \mathrm{~m})$, Kourteri $(527 \mathrm{~m})$, Ordimnos $(511 \mathrm{~m})$ and Eximnos $(504 \mathrm{~m})$. There are also two large and narrow-opened bays, the bay of Kalloni and the bay of Gera (Fig. 1).

Geologically, Lesvos consists mainly of volcanic rocks (andesites, latite andesites, basalts, ignimbrites, peridotites, pyroxen-peridotites, olivinites etc.), although schists and marbles (in the SE part of the island), alluvial deposits (in valleys and near the coasts particularly around the bays of Kalloni and Gera), marls and limestones also occur. Peridotites, pyroxen-peridotites, olivinites are located in the SE (Peninsula of Amali) and in the central part of the island and present a variable degree of serpentinization (NIGMR, 1972-1975).

According to the Emberger and Sauvage climatic diagram (Emberger, 1955, 1959; Sauvage, 1961), Lesvos belongs to the subhumid bioclimatic zone with mild winters. The climatic data come from the meteorological station of Mitilini airport (altitude: 4.8m, period: $1955-1992$ ).

* Institute of Systematic Botany, Section of Ecology and Systematics, Department of Biology, University of Athens, Panepistimiopolis 15784, Athens, Greece. 


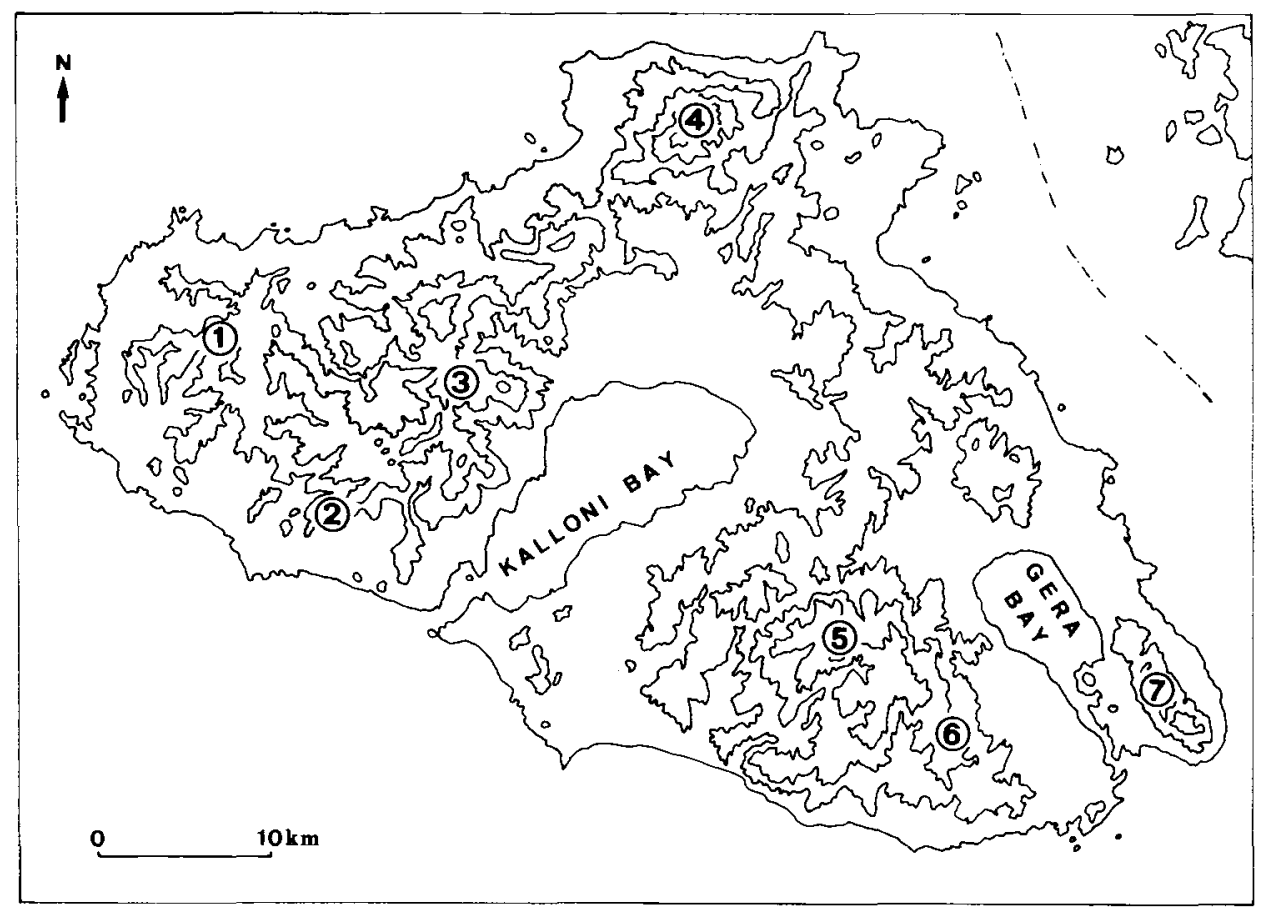

FIG. 1. Map of Lesvos island: 1, Mt Ordimnos (511m); 2, Mt Eximnos (504m); 3, Mt Profitis Ilias (799m); 4, Mt Lepetimnos (968m); 5, Mt Olimbos (968m); 6, Mt Petrovouni (755m); 7, Mt Kourteri (527m). Contour interval: $200 \mathrm{~m}$.

The pteridophytes of Lesvos have never in the past been fully studied. Scattered records are to be found in the works of C.A. Candargy (1889), P.C. Candargy (1897, 1898, 1899), Rechinger (1943), Rauh (1949), Davis (1965), Mavromatis (1974), Yannitsaros (1977, 1979), Edmondson (1982), Strid (1986), Axiotis (1991) and Hansen \& Nielsen (1993). In this paper, which forms part of a wider study of the flora of Lesvos and its surrounding islets, new data are given as a contribution to a better knowledge of the distribution and ecology of these plants. All the records given by Davis (1965) are not original, but reproduce the older records of P.C. Candargy and Rechinger. It is to be noted that certain of the data given here, were been presented in the 5th Congress of the Hellenic Botanical Society (Bazos \& Yannitsaros, 1994b).

\section{MATERIALS AND METHODS}

The floristic list which follows is based mainly on field observations and plant material collected by Artemios Yannitsaros and Ioannis Bazos during the years 1964, 1974, 1979, 1985, 1989, 1990, 1994, 1996 and 1991-1998 respectively. The specimens are deposited in the authors' herbaria held in Athens University (ATHU, some 
duplicates in B and BM). Specimens without numbers collected by Grigorios Yannitsaros (GY) in 1975, 1977 and 1982 are included in the herbarium of $\mathrm{A}$. Yannitsaros. Numbers within brackets, bearing the initials IB and AY refer respectively to the authors' collections, and 'obs.' refers to field observations only. We have also examined specimens collected in April 1997 by the French Pierre Authier which are kept in his private herbarium in Paris. The nomenclature of pteridophyte taxa is in accordance with Greuter et al. (1984) or Zimmer (1991). Especially for the taxa Dryopteris villarii (Bellardi) Schinz \& Thell. subsp. pallida (Bory) Heywood and Polypodium cambricum L. subsp. australe (Fée) Greuter \& Burdet, nomenclature follows Zimmer (in litt.). Families, genera and inferior taxa are arranged in alphabetical order. The names of species whose presence on Lesvos is confirmed are given in bold type. Transliteration of Greek localities is in accordance with Flora Hellenica (Strid \& Tan, 1997) and therefore the islands Corfu, Crete and Rhodes, are mentioned in this paper as Kerkira, Kriti and Rodos respectively. General distribution data have been compiled from the works of Davis (1965), Jalas \& Suominen (1972), Pichi Sermolli (1979), Greuter et al. (1984), Strid (1986) and Tutin et al. (1993).

\section{FLORISTIC LIST}

Equisetaceae

\section{Equisetum arvense $\mathrm{L}$.}

It was reported as new for both Lesvos and the East Aegean by Hansen \& Nielsen (1993) from a river valley near Chidira (W Lesvos). At the same time Snogerup \& Snogerup (1993) reported it as new for the flora of Samos. A previous record of $E$. arvense by Axiotis (1991) is considered as doubtful because of the lack of either a specimen or concrete collection data. In Greece it has scattered appearances on the mainland and seems to be rare in the Aegean Islands as it is distributed only in Kriti (Rechinger, 1943; Jalas \& Suominen, 1972; Turland et al., 1993), Lesvos and Samos (Fig. 2).

General distribution. Europe, $\mathrm{N}$ temperate Asia and $\mathrm{N}$ America.

\section{E. fluviatile L.}

P.C. Candargy's record of 1897 as E. limosum L. 'in humidis regionis inferioris', seems to be the only one for the East Aegean Islands and therefore requires confirmation (see also Hansen \& Nielsen, 1993), although Greuter et al. (1984) accept its presence in the Eastern Aegean. Unfortunately, no voucher specimen is available as Candargy's herbarium is lost (see also Edmondson, 1982, and Diemar \& Seberg, 1989 ). Specimens of a deviating wetland form of $E$. ramosissimum Desf. from the island of Samothraki were at first identified as $E$. fluviatile because of the very wide central cavity of the stem (Strid, in litt.). The presence of such deviating forms of E. ramosissimum on Lesvos is not unlikely. 


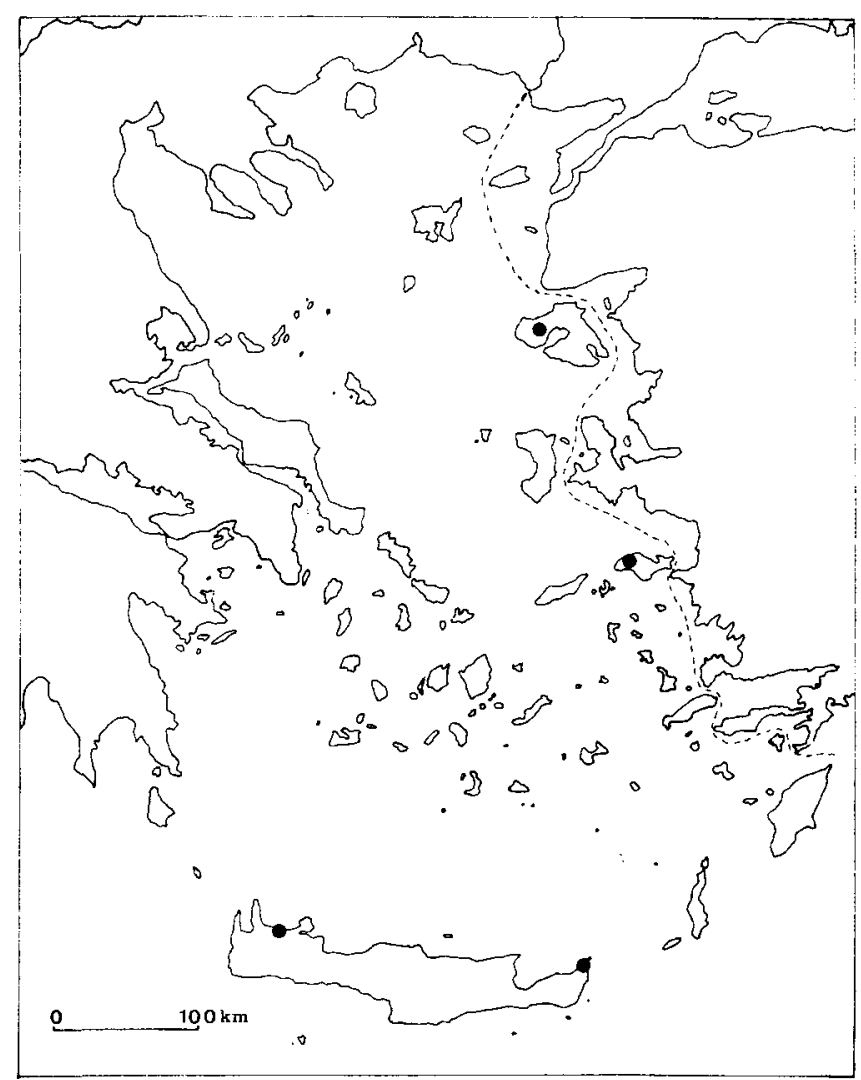

FIG. 2. Known distribution of Equisetum arvense L. in the Aegean Islands.

The species was reported by Lavrentiadis (1956) from Mt Voras (Kaimaktsalan) under the name $E$. limosum as new for Greece. Strid \& Franzén (1982) report the finding of $E$. fluviatile on the same mountain in a marshy area known as Dobro Pole and they point out that the locality is the southernmost in the Balkan peninsula and apparently the only one in Greece. It has also been found by Voliotis (1979) in the same locality on Mt Voras. An older record by Stephanides (1948) from the island of Kerkira as $E$. limosum has not been recently confirmed and, therefore, may be considered very doubtful or erroneous. In the Flora Hellenica database there is also a record from the island of Kefallinia, which is almost certainly incorrect (Strid, in litt.).

General distribution. Temperate regions of the Northern Hemisphere.

\section{E. ramosissimum Desf.}

$=$ E. ramosum $\mathrm{DC}$.

Specimens examined. c. 3km SSE of Mesotopos, Podaras, 9 v 1975 (GY, det. AY as var. virgatum (A. Br.) Milde); northern side of the Bay of Gera, Larsos, moist meadows, 30 viii 
1992 (IB 585); just outside Kalloni, irrigation ditch along the road to Kerami, 10 xi 1992 (IB 685 ); western side of the Bay of Gera, about $3 \mathrm{~km}$ WNW of Evriaki, marshy ground, 26 iv 1994 (IB 1688, AY 8603).

Reported by P.C. Candargy (1898) as very common under the name E. ramosum Schl. P.C. Candargy (1897) also described the variety ' $E$. ramosum Schl. B. icosapleurum: Ad Mitylenem (costis plus minus 20)'

A common species widespread on the Greek mainland and most of the islands.

General distribution. S and C Europe, Asia, Africa and America.

\section{E. telmateia Ehrh.}

Specimens examined. c.3km SSE of Mesotopos, Podaras, marshy ground, 9 v 1975 (GY); ibid., wet ditches, 21 viii 1996 (AY obs.); above Skopelos, Karionas, damp shady place, $30 \mathrm{v}$ 1993 (IB 1110) and 30 xi 1993 (IB 1474); c.1.5km SW of Michou, damp and shady places by a stream, 15 iv 1995 (IB 2204); near Asomatos, Agii Anargiri, wet places by a stream, $22 \times 1996$ (IB 2803).

Recorded by P.C. Candargy (1897): 'In humidis regionis inferioris'.

The species is widespread in Greece and grows on wet ground mainly by streams and springs.

General distribution. Europe, SW and C Asia, NW Africa and N America.

\section{Isoetaceae}

\section{Isoetes duriei Bory}

Specimens examined. c. $0.2 \mathrm{~km}$ SSE of Megali Limni near the crossroads to Ambeliko, seasonal pool in a Pinus brutia forest, 25 v 1994 (IB 1736); c.2km SSE of the crossroads to Tarti, seasonal pool in a Pinus brutia forest, 6 v 1997 (IB 2812); between Pappados and Perama, Malakopetra, seasonal pools and wet open places in phrygana, 4 iv 1998 (IB 3093).

As far as we know, these records are the first for the East Aegean Islands of this mainly west-Mediterranean species which is a very rare plant in Greece (Fig. 3). It grows in seasonally wet habitats and until now it has been reported from the islands of Evvia (Rechinger, 1961), Samothraki (Akeroyd \& Preston, 1987), Agios Evstratios (Snogerup \& Snogerup, 1991) and Paros (Raus, 1996). It is, however, possible that $I$. duriei occurs in more localities than presently known, as it is easily overlooked because of its peculiar habit.

General distribution. Mainly W Mediterranean region, Portugal, Greece and Turkey. The easternmost known limit of its distribution is in the region of Rize in NE Anatolia (Jermy, 1965; Pichi Sermolli, 1979).

\section{I. histrix Bory}

Specimens examined. c. $3.5 \mathrm{~km} \mathrm{~N}$ of Kalloni in a seasonal pool near the road to Petra, 25 iv 1994 (IB 1673, AY 8591), 28 v 1994 (IB 1826) and 25 ii 1995 (IB 2062); near Moni (monastery) 


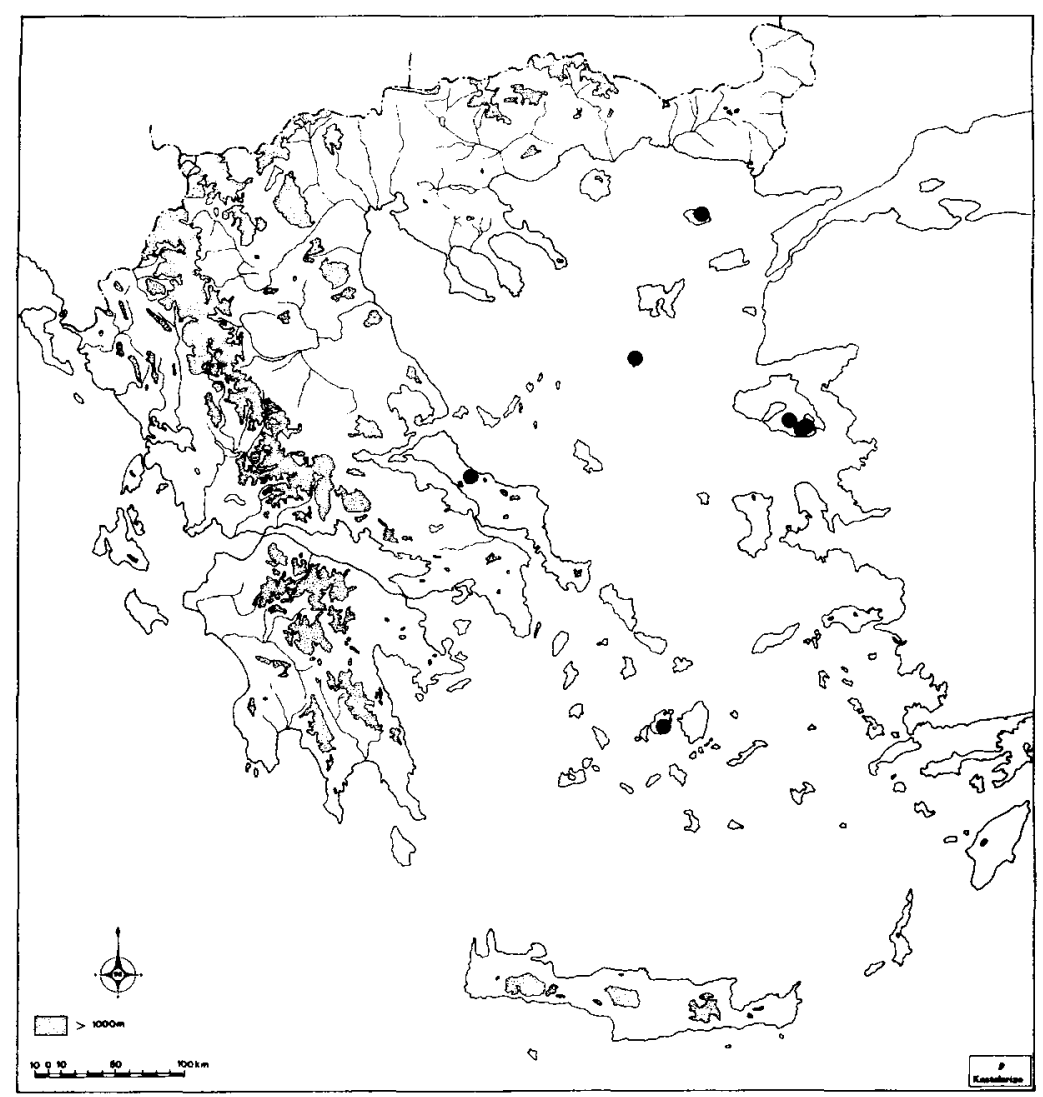

FIG. 3. Known distribution of Isoetes duriei Bory in Greece.

Limonos, NW of Kalloni, temporarily flooded meadows, 28 iv 1994 (AY 8661 ) and 25 ii 1995 (IB 2069); near the crossroads to Aspropotamos (E of Mandamados), seasonal pool, 5 vi 1994 (IB 1975) and 15 v 1995 (IB 2394); c.5km WNW of Lambou Mili, seasonal pool in a Pinus brutia forest, 11 iv 1995 (IB 2121) and $13 \vee 1995$ (IB 2340); c.5.5km NNE of the crossroads to Aspropotamos ( $\mathrm{E}$ of Mandamados), seasonal pool near the road, $15 \mathrm{v} 1995$ (IB 2391); between Agiasos and Vasilika, Mikri Limni, muddy edges of a shallow lake, $16 \mathrm{v}$ 1995 (IB 2421); c. $10 \mathrm{~km}$ SE of Mandamados, seasonal pools in degraded maquis and phrygana near the road to Mitilini, 6 iv 1998 (IB 3129).

New for Lesvos. Known until now from the East Aegean Islands only from Ikaria (Jermy, 1965; Christodoulakis, 1996) and Rodos (Carlström, 1987). An easily overlooked species which grows in habitats similar to $I$. duriei and has rare and scattered appearances on the Greek mainland, the Aegean Islands of Evvia (Rechinger, 1961), Elafonisos off Peloponnisos (Jagel, 1992), Kithira (Yannitsaros, 1998), Kriti (Halácsy, 1904; Rechinger, 1943; Gradstein \& Smittenberg, 1977; Turland et al., 1993), Naxos (Runemark et al., 1960; Böhling, 1995), Paros (Raus, 1996) and the Ionian islands of Kerkira (Halácsy, 1904; Hansen, 1982; Gutermann, 1995), Kefallinia (Gutermann, 1995) and Zakinthos (Halácsy, 1904; Gutermann, 1995). 
According to Strid (in litt.) it is also distributed in the Aegean Islands of Andros, Mikonos, Milos, Tinos and Skiros (Fig. 4).

General distribution. NW Africa, W and S Europe.

\section{Isoetes sp.}

Specimens examined. Between Agiasos and Vasilika, Mikri Limni, muddy edges and shallow water of the lake, 25 v 1994 (IB 1747); c.5km WNW of Lambou Mili, seasonal pools in a Pinus brutia forest, 11 iv 1995 (IB 2125) and 13 v 1995 (IB 2336).

According to Jermy (in litt.) these three specimens are what has been called 1 . heldreichii Wetts., a very rare Greek endemic species described by Wettstein (1886) from the region of Thessalia in central Greece ('submersa in pallude prope Palaeokortion planitiei Thessaliae; legit Dr. Th. de Heldreich, Julio 1885'), but they also match well specimens of $I$. setacea Lam. from France. Therefore, a further study of both micro- and megaspores with SEM, cytology and perhaps isoenzymes is needed for a definitive identification.

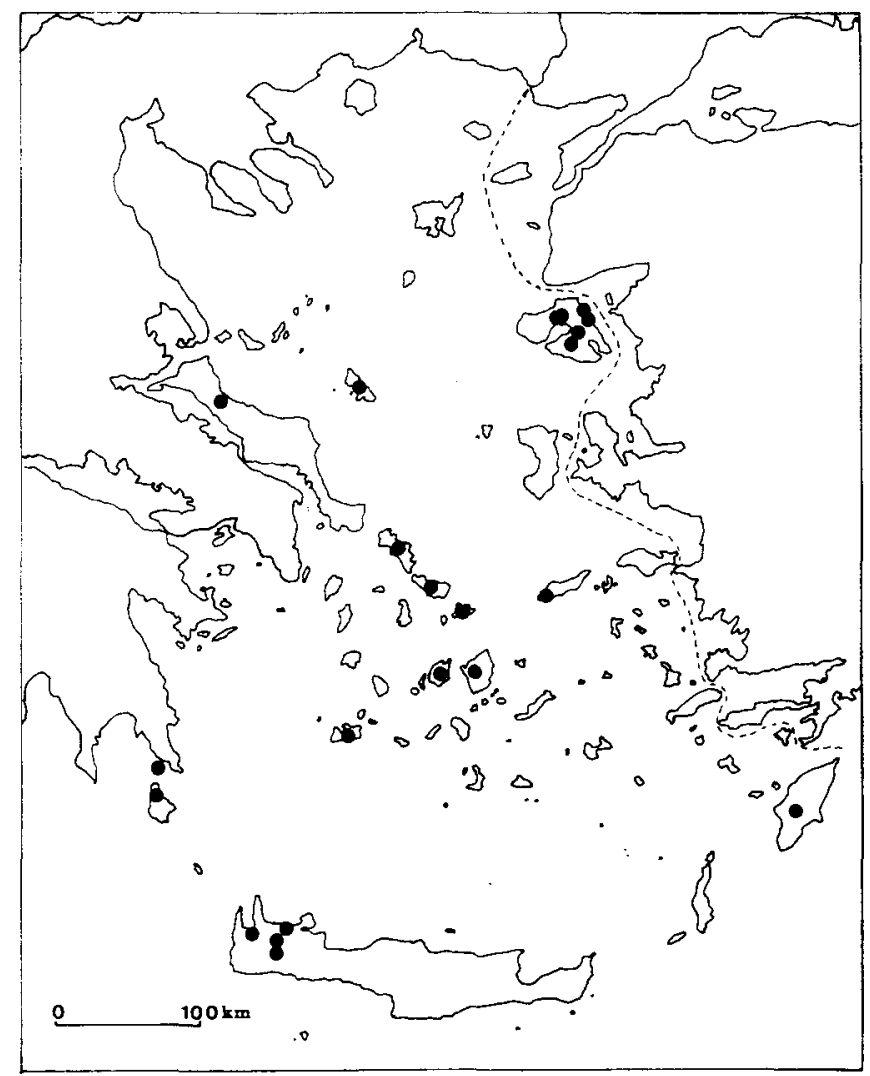

FIG. 4. Known distribution of Isoetes histrix Bory in the Aegean Islands. 


\section{Marsileaceae}

\section{Pilularia minuta Durieu}

Specimens examined. c. $3.5 \mathrm{~km} \mathrm{~N}$ of Kalloni, in a seasonal pool near the road to Petra, $28 \mathrm{v}$ 1994 (IB 1825); c.8km NNE of the crossroads to Aspropotamos (E of Mandamados), in a seasonal pool, 31 v 1994 (IB 1864); c.7.5km NNE of the crossroads to Aspropotamos, in a seasonal pool, 31 v 1994 (IB 1879); c.7km NNE of the crossroads to Aspropotamos, in a seasonal pool, 31 v 1994 (IB 1883); c.6km NNE of the crossroads to Aspropotamos, in a seasonal pool, 2 vi 1994 (IB 1909); between Kapi and Klio, muddy edges of a pond by the road, 4 vi 1994 (IB 1998); between Agiasos and Vasilika, Mikri Limni, muddy edges of a shallow lake, 15 v 1995 (IB 2417).

This very rare species has been found in Greece for the first time by Snogerup et al. (1980) in Psathoura of N Sporades. It has also been reported recently by Snogerup \& Snogerup (1991) from Agios Evstratios. Our findings are the first from the East Aegean Islands, and its Lesvos localities represent the easternmost known distribution limits of the species (Fig. 5). P. minuta is included in the Red Data Book of

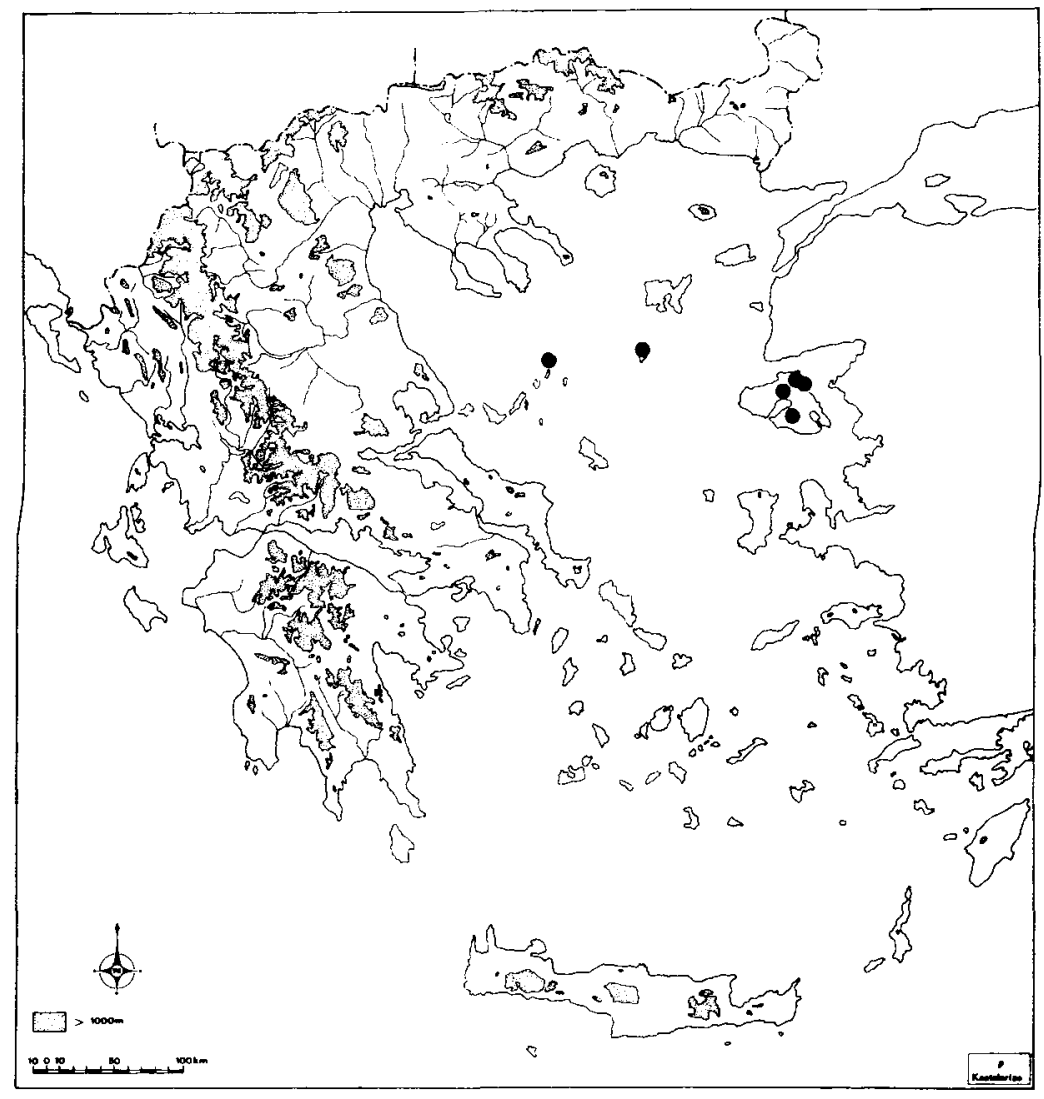

FIG. 5. Known distribution of Pilularia minuta Durieu in Greece. 
Rare and Threatened Plants of Greece (Phitos et al., 1995) as Vulnerable. It is an easily overlooked species with very thin leaves $1-3 \mathrm{~cm}$ long and sporocarps usually buried in the mud (Snogerup, 1995). Most of the localities in which we have found $P$. minuta are in NE part of the island, E of Mandamados, near the summer settlements of Aspropotamos, Agios Stefanos and Palios. Most of the seasonal (vernal) pools in which the species was observed or collected are near the sea, at small distances from one to another, and their surface is not larger than a few square metres. The most interesting accompanying species are Callitriche brutia Petagna, Isoetes histrix, Isolepis cernua (Vahl) Roemer \& Schultes, Juncus tenageia Ehrh., Lythrum borysthenicum (Schrank) Litv. and Ranunculus lateriflorus DC. The whole area mainly serves for stock-breeding (mainly sheep and cows), and increasing construction activity has been noticed during recent years. Of special interest is the area of Mikri Limni located very close to the main road connecting Mitilini with Polichnitos and to the junction of the new road to Achladeri and Kalloni. In the same locality, apart from $P$. minuta, other species relatively rare for Greece such as Baldellia ranunculoides (L.) Parl., Elatine alsinastrum L., Isoetes sp. (see above), Juncus tenageia, Lythrum tribracteatum Sprengel and Myriophyllum alterniflorum DC. have been found (Bazos \& Yannitsaros, in press). We believe that the area of Mikri Limni should be protected not only for its scientifically interesting plant taxa but also for its biological importance with respect to all the Aegean Islands. For all the reasons mentioned above and because of the lack of any protection measures, the characterization of Pilularia minuta as Vulnerable (Snogerup, 1995) must remain in force and immediate measures must be taken to protect this extremely interesting species.

General distribution. Endemic to the Mediterranean region known from a few scattered localities of southern Portugal, southern France, Corsica, Sardinia, Sicily, central and western coastal areas of Morocco and Algeria (Pichi Sermolli, 1979) and the three Aegean Islands mentioned above.

Ophioglossaceae

\section{Ophioglossum vulgatum L.}

Reported from Lesvos by Rauh (1949) without a specified locality or other collection data. Its presence on Lesvos was recently confirmed as A. Hansen and H. Nielsen collected the species on May 1993 from near the village of Agra in W Lesvos (Strid, in litt.). Regarding the rest of the Aegean Islands it has been reported from Andros (Aldén, 1976), Ikaria (Runemark et al., 1960; Christodoulakis, 1996), Naxos (Runemark et al. 1960; Böhling, 1995) and Samothraki (Akeroyd \& Preston, 1987) (Fig. 6). Rechinger's record (1961) of O. lusitanicum L. from Evvia is erroneously reported as $O$. vulgatum by Christiansen (1986a). It has also been reported from the Ionian islands of Kerkira (Stephanides, 1948; Gutermann, 1995) and Kefallinia 


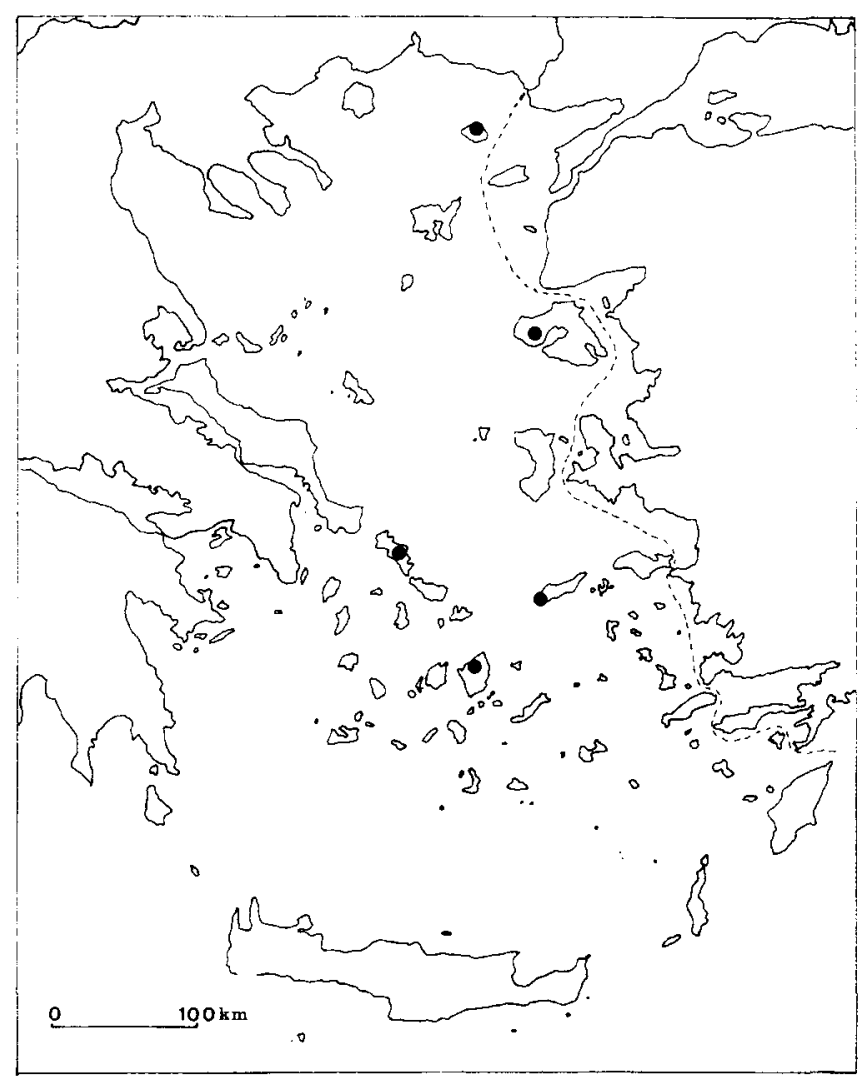

FIG. 6. Known distribution of Ophioglossum vulgatum L. in the Aegean Islands.

(Aldén, 1976; Phitos \& Damboldt, 1985; Gutermann, 1995). The species is rare and scattered in Greece where it grows in wet places, usually damp grassland up to $1800 \mathrm{~m}$ (Aldén, 1976).

General distribution. Temperate regions of the Northern Hemisphere.

\section{Osmundaceae}

\section{Osmunda regalis $\mathrm{L}$.}

Specimens examined. c. $2.5 \mathrm{~km}$ SE of Mesotopos, Kastania, 9 v 1975 (GY) and 3 v 1982 (GY); ibid., humid places, borders of a semi-artificial pool, 3 vi 1985 (AY 7388), 3 xi 1989 (AY 8067) and 1 v 1994 (AY 8702); N side of Mt Eximnos, Aladaris, water spring, 11 vi 1977 (GY); c.3km SSE of Mesotopos, Podaras, in a shallow pit, 13 vi 1977 (GY); Pterounda, in a stream bank growing together with Rhododendron luteum Sweet 27 iv 1994 (AY 8621); c. $2 \mathrm{~km} \mathrm{NW}$ of Parakila, in a stream bank growing together with Rhododendron luteum and Datisca cannabina L., 11 iv 1995 (IB 2091) and 17 v 1995 (IB 2463); c.2.5km NW of Parakila, 
Agia Dosia, shallow pit in a Pinus brutia forest growing together with Rhododendron luteum, 17 xi 1997 (IB obs.).

P.C. Candargy (1897) reports $O$. regalis from Chidira ('ad pagum Chydaera'), a village situated in the western part of Lesvos. The presence of $O$. regalis on Lesvos was confirmed by Yannitsaros (1979) who reported it from a place called Kastania near Mesotopos. This calcifuge, hydrophilous fern, which is common in W Europe, has rare and scattered appearances in Greece, being known from a few localities in western Kriti (Halácsy, 1904; Rechinger, 1943; Gradstein \& Smittenberg, 1977; Zaffran, 1990; Turland et al., 1993), Makedonia (Zaganiaris, 1940; Rechinger, 1943; Jalas \& Suominen, 1972; Pavlidis, 1976) and Lesvos (Fig. 7), whilst older records from Kefallinia (in Halácsy, 1904) and Kerkira (Stephanides, 1948) are doubtful (Phitos \& Damboldt, 1985; Gutermann, 1995). On Lesvos the species occurs only in the western part of the island and always in humid places on volcanic substrata.

General distribution. Northern temperate regions.

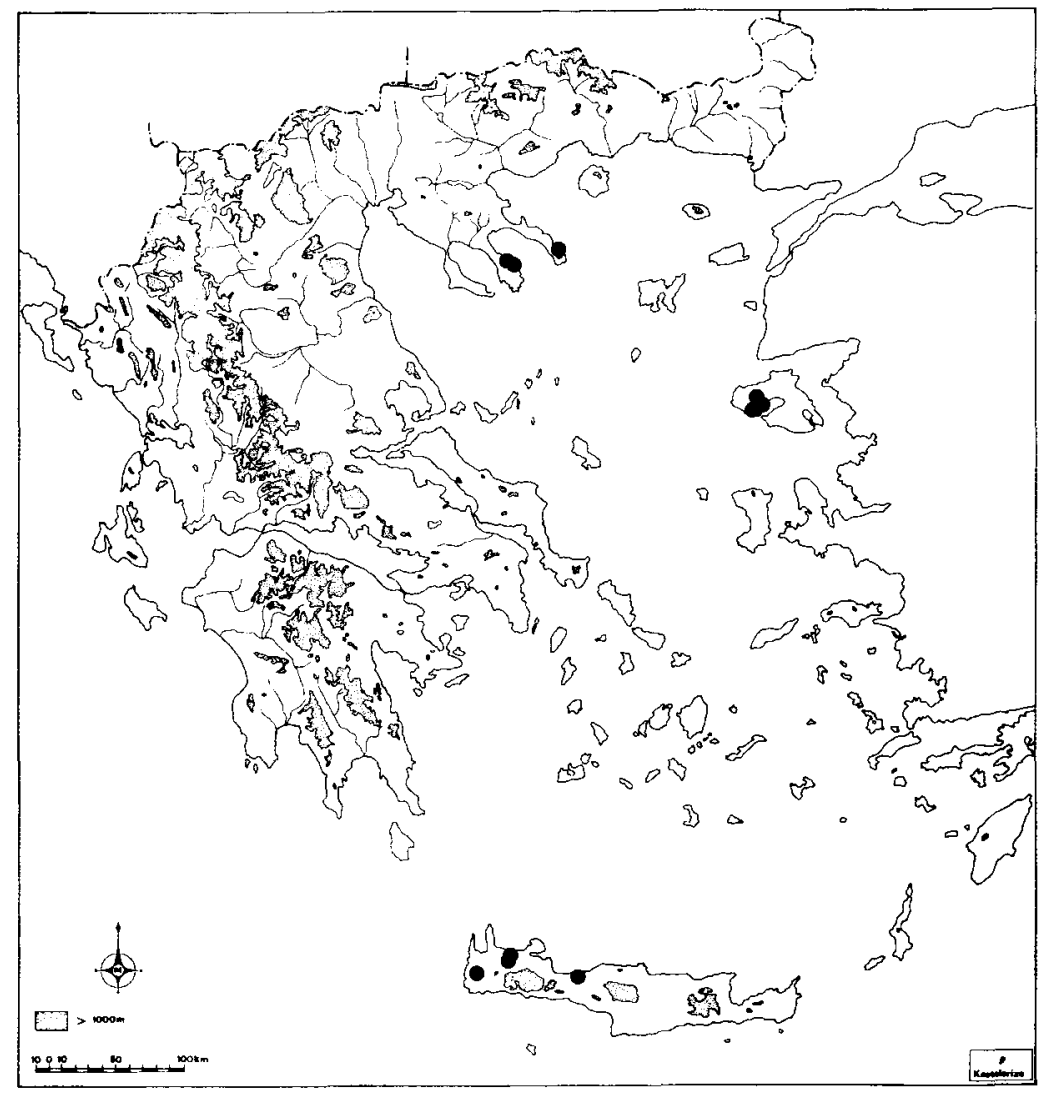

FIG. 7. Known distribution of Osmunda regalis L. in Greece. 


\section{Polypodiaceae}

\section{Adiantum capillus-veneris L.}

Specimens examined. N side of Mt Eximnos, in a water-spring, 11 vi 1977 (GY); near the village Asomatos, Agii Anargiri, streams, wet walls and rocks, 11 vi 1991 (IB 117); above Skopelos, Karionas, wet walls and rocks, 30 xi 1993 (IB 1473) and 17 ix 1994 (IB 2017); peninsula of Amali, summit area of Mt Kourteri, wet rocks, 15 iv 1995 (IB obs.); c. $1.2 \mathrm{~km}$ SW of Michou, damp walls by a spring, 18 xi 1997 (IB obs.).

Reported by C.A. Candargy (1889) and P.C. Candargy (1898) without localities. A common species observed also in several other places on the island.

General distribution. Widespread in temperate and subtropical regions of both Hemispheres, lacking in southern S America.

\section{Anogramma leptophylla (L.) Link $=$ Gymnogramme leptophylla Desv.}

Specimens examined. N side of Mt Eximnos, Aladaris, in humid rock crevices, 11 vi 1977 (GY); c.3.5km N of Kalloni, humid rocks, 25 ii 1995 (IB 2065); SE of the crossroads to Achladeri, humid rock crevices in a Pinus brutia forest, 25 ii 1995 (IB 2072); c.2km NNE of Trigonas, shady rocks and walls, 27 ii 1995 (IB 2080); c.1.5km SW of Michou, walls in an olive grove, 15 iv 1995 (IB 2203); above Skopelos, Karionas, humid and shady places, 14 iv 1995 (IB obs.); peninsula of Amali, summit area of Mt Kourteri, walls and rock crevices, 15 iv 1995 (IB obs.); NW of Nees Kidonies, Xambelia, volcanic rock crevices, 17 iv 1995 (IB 2236); near Andissa, 11 iv 1997 (Authier 14125); near Agia Paraskevi, 15 iv 1997 (Authier 14174); c. $1.5 \mathrm{~km} \mathrm{~S}$ of Pigi, humid and shady places in a Pinus brutia forest, 1 iv 1998 (IB obs.); Cape Koukmos [erroneously as 'Koukos' on the official maps], SSW of Parakila, humid and shady rocks, 2 iv 1998 (IB obs.); north-eastern side of the Bay of Kalloni, SSW of the crossroads to Achladeri, humid rocks in a Pinus brutia forest, 3 iv 1998 (IB obs.).

A. leptophylla is rather common in Lesvos (Fig. 8), although P.C. Candargy (1897) reports it as very rare ('in saxosis humidis'), without an accurate locality. Distributed mainly in the southern part of the Greek mainland, Kriti, and many of the islands.

General distribution. Temperate and tropical regions of both Hemispheres.

\section{Asplenium adiantum-nigrum L.}

Reported from Lesvos by Rauh (1949) without an accurate locality or other collection data. Rauh's record needed confirmation as this taxon is very variable and can easily be confused with its relative $A$. onopteris, which is present on the island (see below). According to Strid (in litt.), A. Hansen \& H. Nielsen have collected both $A$. adiantum-nigrum and $A$. onopteris on Lesvos and although it is difficult to be sure without examining the material critically he believes that the records from Lesvos are correct. Greuter et al. (1984) do not record $A$. adiantum-nigrum for the East Aegean. The species is scattered on the Greek mainland and some of the larger islands, i.e. Evvia (Phitos, 1960; Rechinger, 1961), Ikaria (Christodoulakis, 1996), Kriti (Bergmeier \& Matthäs, 1995), Naxos (Christiansen, 1986b), Samos (Stefani 


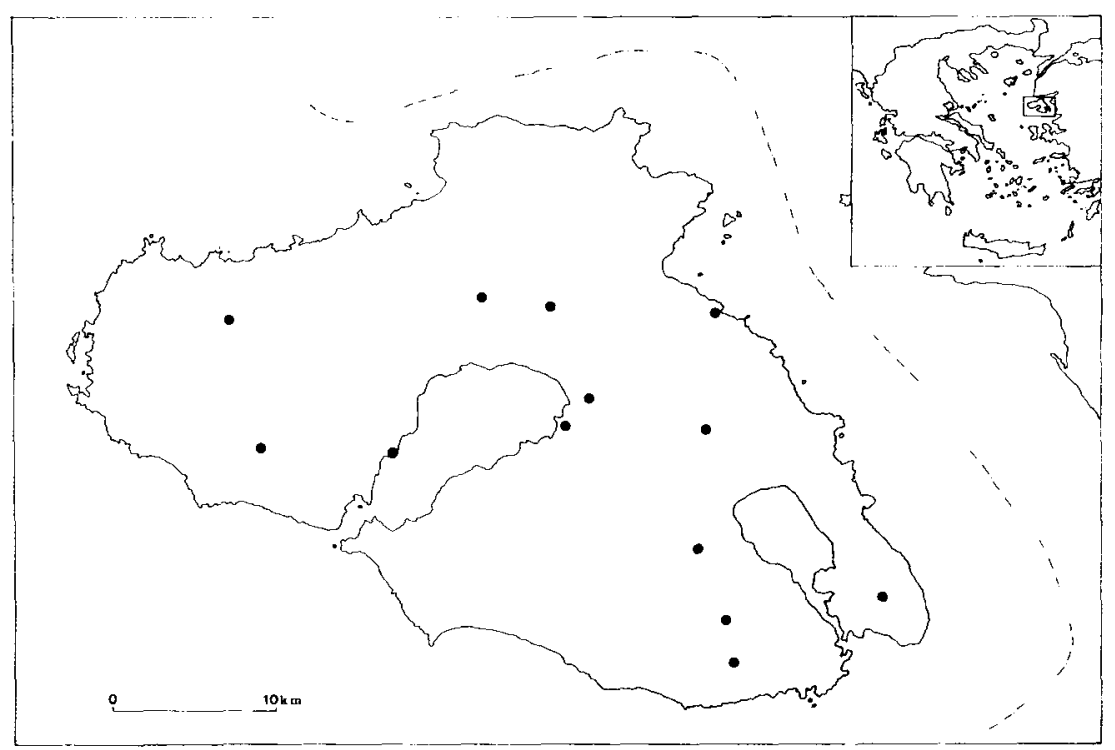

FIG. 8. Known distribution of Anogramma leptophylla (L.) Link in Lesvos.

et al., 1891; Christodoulakis, 1986), Samothraki (Rechinger, 1943), Skopelos (Rechinger, 1949; Phitos, 1967) and Thasos (Strid, in litt.).

General distribution. North temperate regions, N Africa, scattered in S Africa.

\section{A. ceterach L.}

Specimens examined. Between Sigri and Moni Ipsilou, Apolithomeni, volcanic rock crevices, 8 xii 1974 (AY 5734); Mesotopos, 9 v 1975 (GY); above Agiasos, near Sanatorion, walls, 29 iv 1990 (AY 8201); Pelopi, walls, 18 x 1991 (IB 275); above Skopelos, Karionas, rock crevices and old walls, 17 xi 1994 (IB obs.); Mt Olimbos, c.900m, rock crevices, 18 xi 1994 (IB obs.); c. $0.5 \mathrm{~km}$ W of Skalochori, volcanic rock crevices, 19 xi 1994 (IB obs.); Mt Lepetimnos, c.950m, volcanic rock crevices near the summit, 22 xi 1994 (IB obs.); c. $2.5 \mathrm{~km}$ SSE of Sanatorion, rock crevices 23 xi 1994 (IB obs.); c.1.2km SW of Michou, old walls in olive groves, 18 xi 1997 (IB obs.).

Reported from Lesvos by C.A. Candargy (1889), P.C. Candargy (1898) and Rechinger (1943).

The three cytotypes of $A$. ceterach $(2 \mathrm{x}, 4 \mathrm{x}$ and $6 \mathrm{x})$ treated by Viane et al. (1996) as subspecies are not distinct morphologically and can be identified by their stomata and exospore length. The diploid subsp. bivalens (D.E. Mey.) Greuter \& Burdet is known from the islands of Kithira (Greuter \& Rechinger, 1967) and Kefallinia (Phitos \& Damboldt, 1985), the tetraploid subsp. ceterach is widespread on the Greek mainland and most of the islands, and the hexaploid subspecies (not yet described) is known from two localities, one on the island of Poros and one in 
eastern Peloponnisos (Viane et al., 1996). The populations of Lesvos need further study as more than one cytotype may occur on the island.

Dry walls and rock crevices, very often found in dry places exposed to the sun.

General distribution. Mediterranean area to Himalayas, scattered in C Europe.

\section{A. obovatum Viv.}

Specimens examined. Moni Ipsilou, volcanic rock crevices, 12 vi 1998 (IB 3267); between Pterounda and Agra, c.5.2km SSE of Pterounda, rock crevices in a mixed Pinus brutia and P. nigra Arnold, forest, 13 vi 1998 (IB 3282); between Pterounda and Agra, c.3km SSE of Pterounda, rock crevices in a mixed Pinus brutia and P. nigra forest, 13 vi 1998 (IB 3284).

Reported by P.C. Candargy (1897) under the name Asplenium lanceolatum Huds. var. obovatum ('ad pagum Moria') as very rare. As far as we know there are no other records from the island of Lesvos although Edmondson (1982) reports it from the archipelago of Tokmakia, which is located near the NE coast of Lesvos. Our collections confirm the presence of the species on the island (Fig. 9). Regarding the rest of the East Aegean Islands, A. obovatum has been reported only from Ikaria (Rechinger, 1943; Christodoulakis, 1996), Nisiros (Papatsou, 1975) and Fourni (Rechinger, 1949). We have also seen a specimen collected by L.C. Pinatzis on the island of Chios (Delfini, 11.4.1931, No 4937 in herbarium L.C. Pinatzi). To the best of our knowledge this is the first record of $A$. obovatum from Chios. The species is apparently scattered in the southern Greek mainland and the islands (Evvia, Kiklades, Kithira, Poros, Kriti), and very rare in northern Greece as it is reported

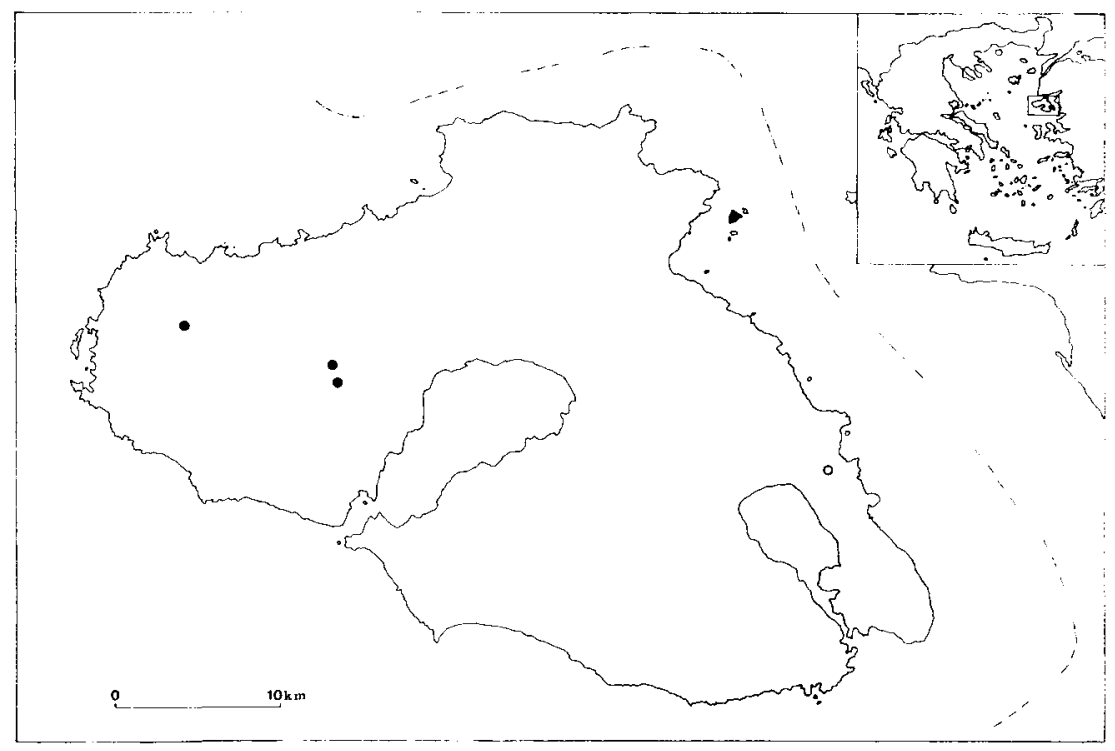

FIG. 9. Known distribution of Asplenium obovatum Viv. in Lesvos. The open dot indicates the first locality given by P.C. Candargy. 
so far only from Samothraki and Athos peninsula (Rechinger, 1943; Jalas \& Suominen, 1972).

A. obovatum comprises two cytologically defined subspecies, the diploid $A$. obovatum subsp. obovatum and the autotetraploid subsp. lanceolatum (Fiori) P. Silva (in Viane et al., 1996). Details on the distribution of both subspecies are given by Jalas \& Suominen (1972), Pichi Sermolli (1979) and Viane et al. (1993). Although their distribution is not yet accurately known, the diploid subspecies is distributed mainly in the Mediterranean region, Portugal and in one station in NW France, whereas the tetraploid subspecies has a western Mediterranean and eastern Atlantic distribution (W Europe, Macaronesia, N Africa). According to Demiriz et al. (1990) and Rasbach et al. (1990) A. obovatum subsp. obovatum consists of three morphologically differentiated varieties i.e. var. obovatum, var. deltoideum Demiriz et al. and var. protobillotii Demiriz et al. One of them, var. protobillotii, can be distinguished from the tetraploid subsp. lanceolatum only by cytological or micro-morphological characters. According to Viane et al. (1996), var. protobillotii is known only from NW Turkey, S Spain and SE Greece, but the distribution of the three varieties in Europe is not yet fully known. Our specimens from above Pterounda (nos. 3282 and 3284) have leaves with acute marginal teeth and we believe that they both belong to var. protobillotii. However, study of chromosome number and micro-characters is needed for a definitive identification.

\section{A. onopteris L.}

Specimens examined. Near Asomatos, Agii Anargiri, shady stream banks, 23 x 1991 (IB 330); above Agiasos, Sanatorion, rock crevices in a Pinus brutia forest, 26 x 1991 (IB 342); above Skopelos, Karionas, shady rock crevices, 17 ix 1994 (IB 2018); Mt Lepetimnos, c.950m, shady rock crevices, 22 ix 1994 (IB 2043); c.1.5km SW of Michou, humid walls and rock crevices, 18 xi 1997 (IB 3031).

Recorded by P.C. Candargy (1897) from mountains as A. Adiantum-nigrum L. var. acutum Bory.

Widespread at low altitudes up to $1000 \mathrm{~m}$ (rarely higher) in the Greek mainland and several of the islands.

General distribution. Mediterranean region and W Europe.

\section{A. trichomanes L. subsp. quadrivalens D.E. Mey.}

Specimens examined. Near Asomatos, Agii Anargiri, old walls, 23 x 1991 (IB 327); above Agiasos, Sanatorion, rock crevices in a Pinus brutia forest, 26 x 1991 (IB 343); above Skopelos, Karionas, shady rock crevices, 30 xi 1993 (IB 1472) and 17 ix 1994 (IB 2016); Mt Lepetimnos, c. $950 \mathrm{~m}$, volcanic rock crevices near the summit, 22 xi 1994 (IB obs.); between Agiasos and Megalochori, c. $3 \mathrm{~km}$ SSE of Sanatorion, rock crevices, 23 xi 1994 (IB obs.); c. $1.2 \mathrm{~km} \mathrm{SW}$ of Michou, walls in olive groves, humid and shady rocks, 18 xi 1997 (IB obs.).

Recorded by P.C. Candargy (1897) as A. Trichomanes. 
Amongst rocks and on walls. Distributed in southern and north-eastern parts of the Greek mainland and many of the islands.

General distribution. Widely distributed in both the $\mathrm{N}$ and the $\mathrm{S}$ Hemispheres.

\section{Cheilanthes acrostica (Balbis) Tod.}

Specimens examined. Between Sigri and Moni Ipsilou, Apolithomeni, 8 xii 1974 (AY 5735); by the road from Mesotopos to Eresos near the crossroad to Skala Eresou, Psinia, 6 v 1975 (GY); near Loutra, c.0.2km WSW of the crossroads to Koundouridia, rock crevices, 21 ix 1994 (IB 2035); Trigonas, dry walls along the main road of the village, 23 ix 1994 (IB 2047); c.3.5km SW of Moria, c.80m, 9 iv 1997 (Authier 14075); near Mistegna, E Lesvos, 13 iv 1997 (Authier 14141).

Crevices of dry rocks. The species grows on a variety of substrata (Zimmer, 1991) and is very common in S Greek mainland and most of the islands.

General distribution. S Europe, N Africa, SW Asia to the Himalayas.

C. persica (Bory) Mett. ex Kuhn

Recorded by P.C. Candargy (1897) under the name C. Szovitzii F. et M., as very rare in mountainous areas ('regio montana'), without precise locality. The species is not marked for Lesvos in its distribution map in Greece (Zimmer, 1991) and therefore its presence on the island requires confirmation. C. persica is very rare and scattered on the Greek mainland and the islands of Kastellorizo (Greuter, 1979), Kriti (Rechinger, 1943; Zaffran, 1990; Zimmer, 1991; Turland et al., 1993), Samos (Rechinger, 1943; Christodoulakis, 1986), Samothraki (Rechinger, 1943; Akeroyd \& Preston, 1987) and Simi (Carlström, 1987). According to Strid (in litt.) I. Dinter's (1995) records from Chios and Lesvos have not been confirmed by a specialist and are considered as doubtful.

General distribution. S Europe, N Africa extending through SW Asia to the W Himalayas.

\section{Cystopteris fragilis (L.) Bernh.}

Specimens examined. c. $1 \mathrm{~km}$ E of Mesotopos, Karaspilios, in a small cave, vii 1964 (AY s.n., specimen lost); Mt Olimbos, c.600m, shady places in Castanea sativa Miller forest, 17 vi 1991 (IB 192); above Skopelos, Karionas, shady places in scrub, 17 ix 1994 (IB 2015); SSE of Agiasos, summit area of Mt Petrovouni, humid rock crevices, 11 v 1995 (IB 2266); between Agra and Pterounda, c. $4 \mathrm{~km}$ NE of Agra, shady places of a mixed deciduous forest, $17 \mathrm{v} 1995$ (IB 2457); W side of Mt Olimbos, c.750m, shady and humid places near a spring, 8 vi 1998 (IB 3160 ).

Reported by P.C. Candargy (1897) from Mt Olimbos, as rare. Our records confirm the presence of $C$. fragilis on the island. The species has small and scattered populations but is certainly not as rare as P.C. Candargy suggested (Fig. 10). Distributed throughout the Greek mainland and the larger of the islands (Evvia, Ikaria, Kriti, 


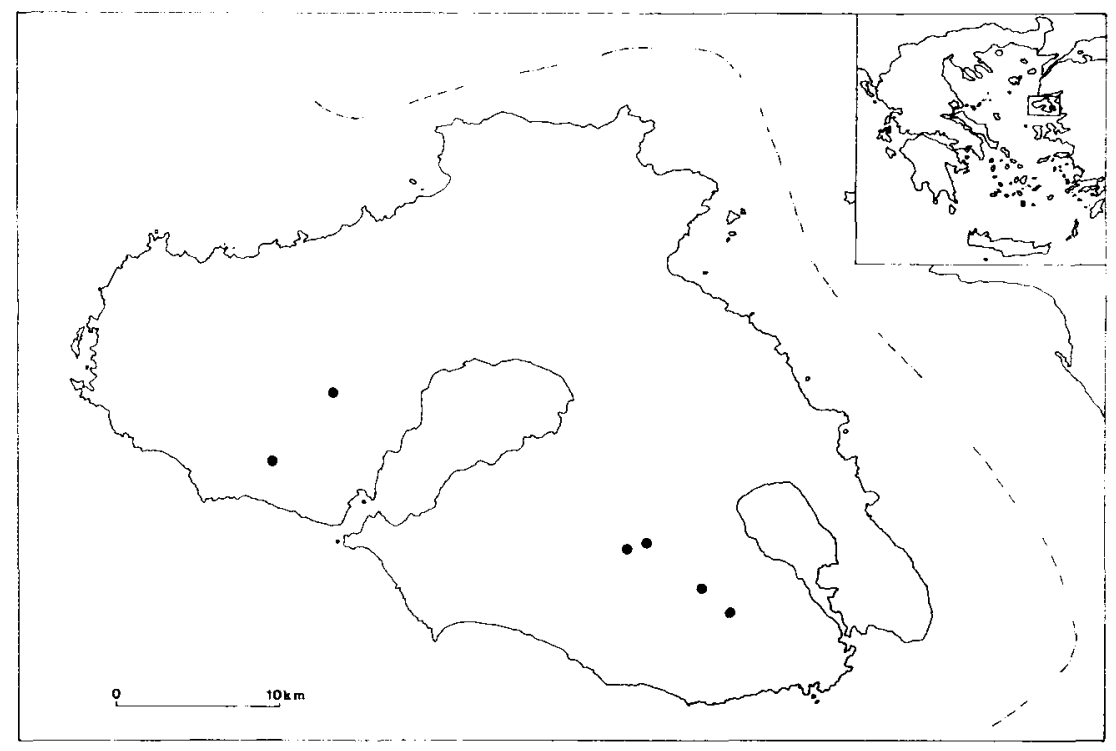

FIG. 10. Known distribution of Cystopteris fragilis (L.) Bernh. in Lesvos.

Samos, Samothraki and Thasos). An old record from Kithira is very doubtful and probably erroneous (see Greuter \& Rechinger, 1967).

General distribution. A cosmopolitan and very variable species, widespread in both Hemispheres.

Dryopteris villarii (Bellardi) Schinz \& Thell. subsp. pallida (Bory) Heywood

Specimens examined. N side of Mt Eximnos, Aladaris, 11 vi 1975 (GY); NE and above Mesotopos, Aso Kambos, 11 vi 1975 (GY); above Agiasos, Sanatorion, humid places in Pinus brutia forest, 29 iv 1990 (AY 8202) and $26 \times 1991$ (IB 345); near Agiasos, Kastelli, rock crevices, 15 vi 1991 (IB 78); Megalochori, shady places in Pinus brutia forest, 11 xi 1992 (IB 691); Mt Olimbos, c. $850 \mathrm{~m}$, rock crevices, 18 ix 1994 (IB 2024); c.0.4km SE of Filia, rock crevices, 19 ix 1994 (IB 2027); Mt Lepetimnos, c.950m, humid and shady holes in volcanic rocks, 22 ix 1994 (IB 2042); Mt Lepetimnos, above Pelopi, Quercus coccifera L. scrub, 22 ix 1994 (IB 2045); SSE of Agiasos, near the summit area of Mt Petrovouni, stone fences in Castanea sativa forest, 23 ix 1994 (IB 2046); between Agra and Pterounda, c.4km NE of Agra, shady places of a mixed deciduous forest, 17 v 1995 (IB 2461).

Reported by P.C. Candargy (1898) as Nephrodium rigidum Desv. B. australe Ten. from mountainous regions without specific locality and by Rechinger (1943) from Mt Olimbos near Agiasos and Stipsis.

Forests, humid and shady places, rock crevices. Common throughout the Greek mainland (except in the extreme north) and many of the islands.

General distribution. Widespread in the $\mathrm{C}$ and $\mathrm{E}$ Mediterranean region, scattered in Spain. 


\section{D. filix-mas (L.) Schott}

The only record for the flora of Lesvos and apparently for the flora of all East Aegean Islands is that of Axiotis (1991). Unfortunately, the lack of specimen and other collection data, obliges us to consider the occurrence of this species in Lesvos as very doubtful as it has probably been confused with $D$. villarii subsp. pallida. The only Aegean records of D. filix-mas are from Samothraki (in Rechinger, 1943) and Thasos (Christiansen, 1986c). Older records from Kriti are considered by Greuter (1974) as very doubtful. The species is rather widespread in damp deciduous forests of the Greek mainland. Unconfirmed records from the Ionian islands of Kefallinia, Levkas and Zakinthos (in Halácsy, 1904; Hofmann, 1968; Jalas \& Suominen, 1972) are probably incorrect and belong to $D$. villarii subsp. pallida.

Notholaena marantae (L.) Desv.

$=$ Cheilanthes marantae $(\mathrm{L}$.$) Domin$

Specimen examined. Peninsula of Amali, between Charamida and Akrotirio (Cape) Maleas, serpentine rocks in a Pinus brutia forest, $20 \times 1996$ (IB 2773).

P.C. Candargy (1897) reports $N$. marantae from Lesvos as rare, 'in saxosis', without specific locality but to our knowledge there are no other records from the island. Our finding confirms the presence of the species on Lesvos. It seems that our locality is the only one known from the East Aegean Islands. In the Greek mainland it is recorded mostly from inland localities up to $2100 \mathrm{~m}$ (see Zimmer, 1991), whereas in the Aegean Islands it is very rare and known elsewhere only from Evvia (Rechinger, 1961; Zimmer, 1991). According to Greuter (1974) the Cretan records of the species are very doubtful. Recently, $N$. marantae has been reported by Viane et al. (1996) from near Methana in E Peloponnisos, which is the southernmost known limit of its distribution in Greece (see also Constantinidis, 1997) (Fig. 11). The species is calcifuge and usually grows on serpentine but not exclusively, because it also occurs on silicate rocks containing manganese (see Zimmer, 1991).

General distribution. S and C Europe, NW Africa, SW Asia, Himalayas and E tropical Africa.

\section{Polypodium cambricum L. subsp. australe (Fée) Greuter \& Burdet}

Specimens examined. W of Mesotopos, Kavatsanos, humid rocks by the road to Eresos, 10 xii 1974 (AY 5753); above Pelopi, humid and shady rocks, 18 x 1991 (IB 278); near Asomatos, rock crevices in olive groves, 5 ii 1992 (IB 359); near Skalochori, humid rocks, 5 iv 1993 (IB 733); near Filia, humid and shady rocks, 5 iv 1993 (IB 742); Mt Olimbos, humid rock crevices, 18 v 1993 (IB 957); c.0.8km SE of Filia, humid rock crevices, 19 ix 1994 (IB 2025); c. $0.4 \mathrm{~km}$ SE of Filia, rock crevices, 19 ix 1994 (IB 2026); c.2.8km W of Vatousa, rock crevices, 19 ix 1994 (IB 2029); Mt Lepetimnos, above Pelopi, humid and shady rocks in Quercus coccifera scrub, 22 ix 1994 (IB 2044); c.2km NNE of Trigonas, humid and shady rocks, 27 ii 1995 (IB 2081).

Records of $P$. vulgare L. from Lesvos (C.A. Candargy, 1889; P.C. Candargy, 1898; 


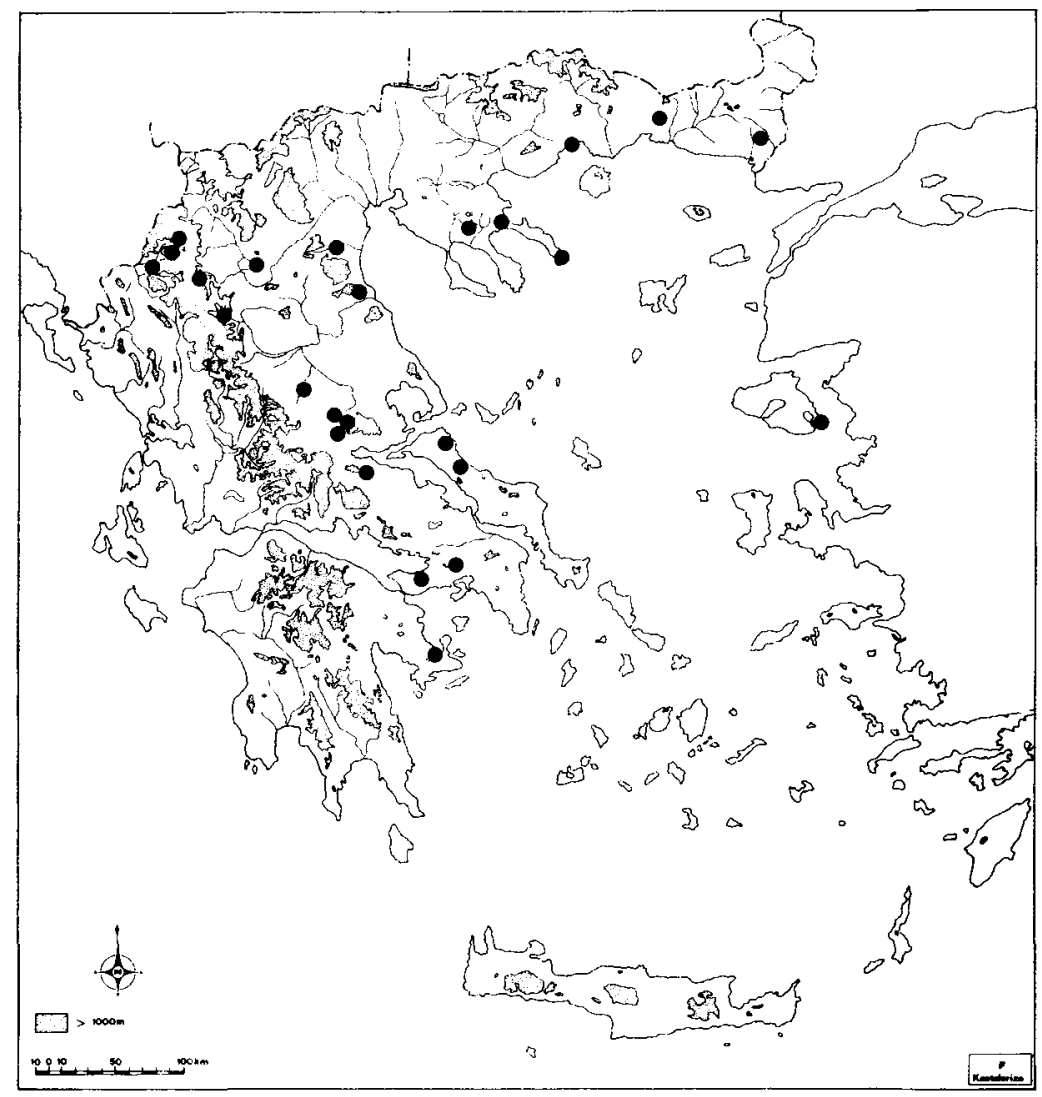

FIG. 11. Known distribution of Notholaena marantae (L.) Desv. in Greece.

Rauh, 1949) probably belong to this taxon. The polyploid complex of $P$. vulgare requires further study as the taxonomy and distribution of its three members is somewhat unsettled (Strid, in litt.). $P$. vulgare occurs in the mountains of the Greek mainland especially above $1000 \mathrm{~m}$, whereas $P$. cambricum is widespread at low altitudes on the islands and a few coastal localities on the mainland.

General distribution. Mediterranean region and W Europe.

P. vulgare L.

Recorded from Lesvos by C.A. Candargy (1889) ('sur les rochers de la rivière Ouziá'), by P.C. Candargy (1898) as common without any other collection data, and by Rauh (1949) also without specific locality and other collection data. The presence of $P$. vulgare on Lesvos needs confirmation as these records probably belong to $P$. cambricum subsp. australe, which is rather widespread on the island (see above). 


\section{Polystichum setiferum (Forsskål) Woynar}

Specimen examined. Between Agiasos and Gera's Bay, above the village of Michou, humid and shady stream bank, 26 iv 1994 (IB 1698, AY 8608).

As far as we know this is the first record of the genus Polystichum for the East Aegean Islands. The species is scattered in deciduous forests throughout the Greek mainland and has rare appearances in the Aegean Islands as it is distributed only in Andros (Strid, in litt.), Evvia (Phitos, 1960; Rechinger, 1961), Kriti (Greuter, 1973), Naxos (Runemark et al., 1960; Böhling, 1995), Samothraki and Thasos (Rechinger, 1943) (Fig. 12).

General distribution. Temperate and tropical regions of both Hemispheres.

\section{Pteridium aquilinum (L.) Kuhn}

Specimens examined. Near Chidira, humid places by a stream, 29 viii 1979 (AY obs.); c.3km SSE of Mesotopos, Podaras, moist places by a stream, very common, 17 x 1981 (AY obs.);

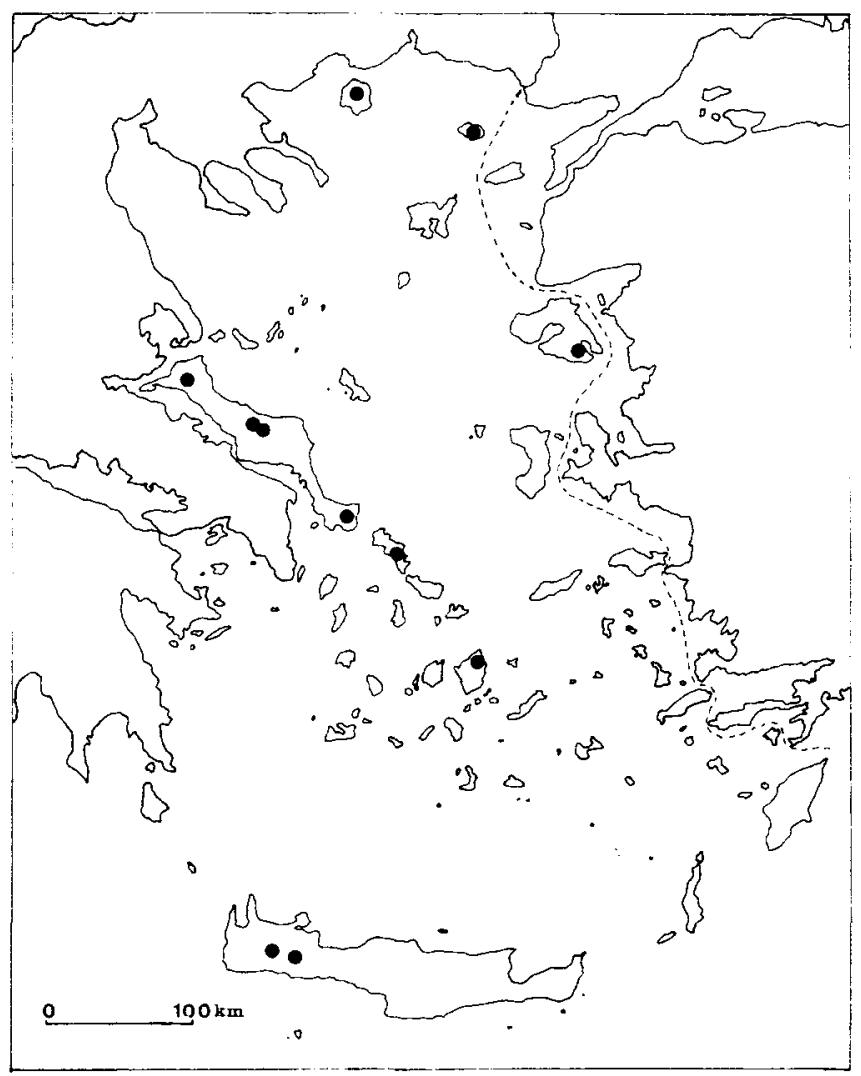

FIG. 12. Known distribution of Polystichum setiferum (Forsskål) Woynar in the Aegean Islands. 
c. $2.5 \mathrm{~km}$ SE of Mesotopos, Kastania, in the vicinity of two semi-artificial water-pools and other wet places, $17 \times 1981$ (AY obs.), 3 xi 1989 (AY photo!) and 8 iv 1990 (AY obs.); c.1.8km SSE of Mesotopos, Sistria, shady places by paths, 3 xi 1989 (AY obs.); above Skopelos, Karionas, forest clearings and humid uncultivated fields, 11 xi 1992 (IB 690); Mt Olimbos, woodland openings, 18 xi 1994 (IB obs.); Mt Lepetimnos, woodland openings, 22 xi 1994 (IB obs.); between Agiasos and Megalochori, c. $2.5 \mathrm{~km}$ SSE of Sanatorion, Castanea sativa forest, 23 xi 1994 (IB obs.); summit of Mt Profitis Ilias SE of Vatoussa, clearings of Pinus nigra forest, 27 v 1994 (IB obs.); c.2km NW of Parakila, in a stream bank, 11 iv 1995 (IB obs.); c.1.2km SW of Michou, stream banks and olive groves, 18 xi 1997 (IB obs.).

Recorded by P.C. Candargy (1898) as common 'in regione montana', but we have collected or observed $P$. aquilinum in lowland localities as well.

Humid and shady places in forest clearings, cleared woodland, and on stream banks. Common throughout the Greek mainland and the larger islands.

General distribution. An almost cosmopolitan species.

\section{Selaginellaceae}

\section{Selaginella denticulata (L.) Spring}

Specimens examined. Between Sigri and Moni Ipsilou, Apolithomeni, humid ground, 8 xii 1974 (AY 5744); W of Mesotopos, road to Eresos, Kavatsanos, humid rocks by the road, 10 xii 1974 (AY 5754); between Mandamados and Kapi, in a Pinus brutia forest, 26 x 1991 (IB 312); near Asomatos, old walls in olive groves, 5 ii 1992 (IB 358); above Skopelos, Karionas, shady and humid rocks, 17 xi 1994 (IB obs.); near Agiasos, Sanatorion, humid ground, 23 xi 1994 (IB obs.); SE of the crossroads to Achladeri, humid rock crevices in a Pinus brutia forest, 25 ii 1995 (IB 2073); c.1.2km SW of Michou, humid walls in olive groves, 18 xi 1997 (IB obs.).

Recorded by C.A. Candargy (1889) as very common ('sur les pierres humides de barrage des oliviers. Aux environs de Mit.') and by P.C. Candargy (1898) as common in lowland localities ('reg. inf.').

Humid ground, shady and humid rocks and walls. Very common in Greece.

General distribution. Mediterranean region.

\section{DISCUSSION}

During our long-term study of the flora of Lesvos (begun in 1964) it became apparent that the knowledge of its pteridophyte flora was insufficient. Most old records, and especially those of C.A. Candargy (1889), P.C. Candargy $(1897,1898,1899)$ and Rauh (1949), are vague and lack full collection data. After the loss of P.C. Candargy's herbarium, the necessity for an integral study of the flora of Lesvos, complying with modern scientific concepts became imperative. Therefore, our efforts were focused to verify the presence on the island of taxa recorded by older authors and to add as much new data as possible. To this effect we have made collections in the largest possible number of areas and habitats of the island. In recent years, special consideration has been given to the investigation and collection of specimens 
from seasonal pools, which are located mainly in the north-eastern, central and western parts of the island, on schists and volcanic substrata. Seasonal pools are among the most fragile and threatened habitats in Greece and the Mediterranean region, and are often a habitat for rare plants, which may be greatly isolated from other populations. Plants of special interest that have been found in these habitats include the pteridophytes Isoetes duriei, I. histrix and Pilularia minuta. These are species of mainly west-Mediterranean or west-European distribution with rare and scattered appearances in Greece, and are probably undercollected because of their small size, peculiar morphology and the particularity of their habitats (Snogerup \& Snogerup, 1991; Bazos \& Yannitsaros, 1994a).

The pteridophyte flora of Lesvos comprises 24 taxa belonging to 16 genera and 7 families. Isoetes duriei, Pilularia minuta and Polystichum setiferum are apparently new for the flora of the East Aegean Islands and I. histrix is new for Lesvos. The genus Isoetes and the family Isoetaceae are new for the flora of Lesvos, and the genera Pilularia and Polystichum as well as the family Marsileaceae are new for the flora of the East Aegean Islands as a whole. Although the occurrence of four previously recorded taxa (Cheilanthes persica, Dryopteris filix-mas, Equisetum fluviatile and Polypodium vulgare) is considered as doubtful or incorrect, the presence of three more rare species, Asplenium adiantum-nigrum, Notholaena marantae and Ophioglossum vulgatum, is confirmed.

Some of the 24 taxa of Pteridophyta of Lesvos seem to be rare or even more threatened all over Greece, because of the instability of their habitats. As already mentioned Pilularia minuta is included in the Red Data Book of Rare and Threatened Plants of Greece (Phitos et al., 1995) and the WCMC (World Conservation Monitoring Centre) lists for Greece (1997), as Vulnerable and is also protected under the Bern Convention (1979). It is to be noted that seasonal pools (Mediterranean temporary ponds) are included in the Directive $92 / 43 /$ EU priority habitats. Osmunda regalis is included in the WCMC lists for Greece with '?' whilst Isoetes duriei is not included in any list of threatened plants. Furthermore neither of these two species is protected under any international convention and we recommend that both $I$. duriei and $O$. regalis be included in the WCMC lists for Greece as Vulnerable (V) and Rare ( $R$ ) respectively. We also consider necessary that protection measures must be taken by the Greek State for all these three plants (i.e. I. duriei, O. regalis and $P$. minuta) and their sensitive habitats.

The East Aegean Islands constitute a separate phytogeographic entity with considerable particularities. They also constitute one of the thirteen floristic regions of Greece as adopted for the Flora Hellenica project (Strid \& Tan, 1997). For this reason we have compiled up-to-date data regarding the pteridophyte flora of the five largest East Aegean Islands, namely Lesvos, Chios, Ikaria, Samos and Rodos (Table 1). We believe that the pteridophyte flora of four of these islands (Lesvos, Ikaria, Samos and Rodos) can be considered well-known, but for Chios, whose flora is still under study by research teams of the Lund and Patras Universities, the data are as yet insufficient. 
TABLE 1. Comparative table of Pteridophyta of the larger East Aegean Islands: + , presence confirmed; ?, presence requiring confirmation; - , not reported or records unconfirmed and very doubtful.

\begin{tabular}{|c|c|c|c|c|c|}
\hline & Lesvos & Chios & Ikaria & Samos & Rodos \\
\hline Adiantum capillus-veneris $\mathrm{L}$. & + & + & + & + & + \\
\hline Anogramma leptophylla (L.) Link & + & - & + & + & + \\
\hline Asplenium adiantum-nigrum L. & + & - & + & $?$ & $?$ \\
\hline A. bourgaei Milde & - & - & - & - & + \\
\hline A. ceterach $\mathrm{L}$. & + & + & + & + & + \\
\hline A. obovatum Viv. & + & - & + & - & - \\
\hline A. onopteris $\mathrm{L}$ & + & - & + & + & - \\
\hline $\begin{array}{l}\text { A. trichomanes L. subsp. quadrivalens } \\
\text { D.E. Meyer }\end{array}$ & + & + & + & + & - \\
\hline Athyrium filix-femina (L.) Roth & - & - & + & - & - \\
\hline Cheilanthes acrostica (Balbis) Tod. & + & + & + & + & + \\
\hline C. guanchica Bolle & - & - & + & - & - \\
\hline C. persica (Bory) Mett. ex Kuhn & $?$ & - & - & + & - \\
\hline Cosentinia vellea (Aiton) Tod. & - & - & + & + & + \\
\hline Cystopteris fragilis (L.) Bernh. & + & - & + & + & - \\
\hline Dryopteris filix-mas (L.) Schott & - & - & - & - & - \\
\hline $\begin{array}{l}\text { D. villarii (Bellardi) Schinz \& Thell. } \\
\text { subsp. pallida (Bory) Heywood }\end{array}$ & + & + & + & + & + \\
\hline Equisetum arvense L. & + & - & - & + & - \\
\hline E. fluviatile $\mathrm{L}$ & $?$ & - & - & - & - \\
\hline E. ramosissimum Desf. & + & - & + & + & + \\
\hline E. telmateia Ehrh. & + & - & + & + & + \\
\hline Isoetes duriei Bory & + & - & - & - & - \\
\hline I. histrix Bory & + & - & + & - & + \\
\hline Isoetes $\mathrm{sp}$ & + & - & - & - & - \\
\hline Notholaena marantae (L.) Desv. & + & - & - & - & - \\
\hline Ophioglossum lusitanicum $\mathrm{L}$. & - & - & - & - & + \\
\hline O. vulgatum $\mathrm{L}$ & + & - & + & - & - \\
\hline Osmunda regalis $\mathrm{L}$. & + & - & - & - & - \\
\hline Pilularia minuta Durieu & + & - & - & - & - \\
\hline $\begin{array}{l}\text { Polypodium cambricum L. subsp. australe } \\
\text { (Fée) Greuter \& Burdet }\end{array}$ & + & - & + & + & + \\
\hline$P$. interjectum Shivas & - & - & + & - & - \\
\hline P. vulgare $\mathrm{L}$. & $?$ & - & - & - & - \\
\hline Polystichum setiferum (Forsskål) Woynar & + & - & - & - & - \\
\hline Pteridium aquilinum (L.) Kuhn & + & + & + & + & $?$ \\
\hline Pteris dentata Forsskål & - & - & + & - & - \\
\hline P. vittata $\mathrm{L}$ & - & - & + & + & - \\
\hline Selaginella denticulata (L.) Spring & + & + & + & + & + \\
\hline
\end{tabular}

The known pteridophyte flora of the East Aegean Islands now comprises 33 taxa. Only five of these are present in all the larger East Aegean Islands, i.e. Adiantum capillus-veneris, Asplenium ceterach, Cheilanthes acrostica, Dryopteris villarii subsp. 
pallida and Selaginella denticulata. This number is probably an underestimation as the flora of Chios is insufficiently known. For the time being, taxa such as Anogramma leptophylla, Equisetum telmateia, E. ramosissimum and Polypodium cambricum subsp. australe, which are relatively common, have not yet been recorded from Chios.

Of the taxa listed in Table 1, Isoetes duriei, Isoetes sp., Notholaena marantae, Osmunda regalis, Pilularia minuta and Polystichum setiferum are up to now known only from Lesvos, whilst Athyrium filix-femina, Cheilanthes guanchica, Polypodium interjectum and Pteris dentata are known only from Ikaria, Asplenium bourgaei and Ophioglossum lusitanicum only from Rodos, and Cheilanthes persica only from Samos. Furthermore, Pteris vittata is known only from Samos and Ikaria and Ophioglossum vulgatum only from Lesvos and Ikaria.

Finally, the pteridophyte flora of Lesvos seems to be the richest with 24 taxa known up to now, followed by that of Ikaria with 23 taxa.

\section{ACKNOWLEDGEMENTS}

We express our special thanks to Dr Brigitte Zimmer (Berlin) for having determined or confirmed the determinations of a part of our collections, Mr Clive Jermy (London) for having confirmed the determinations of our Isoetes specimens as well as for his specially enlightening comments regarding this difficult genus, Prof. Arne Strid (Copenhagen) who put at our disposal data from the Flora Hellenica database, Mr Constantinos Pinatsis (Athens) who put at our disposal specimens from the private herbarium of his father Leonidas C. Pinatzis, Mr Pierre Authier (Paris) who put at our disposal specimens from his 1997 trip to Lesvos and finally Mrs Meni Ouzounelli and her husband Mr Giorgos Mastrandonakis (Mitilini) who took and accompanied us to some not easily accessible areas of Lesvos.

\section{REFERENCES}

AKEROYD, J. R. \& PRESTON, C. D. (1987). Floristic notes from the Aegean region of Greece. Willdenowia 16: 349-372.

ALDÉN, B. (1976). Floristic reports from the high mountains of Pindhos, Greece. Bot. Not. 129(3): 297-321.

AXIOTIS, M. (1991). Ta fita tis Lesvou, mesa apo ti glossa tou laou tis (epistimonikes ke dimodis onomasies). Lesviaka 13: 5-18 (in Greek).

BAZOS, I. \& YANNITSAROS, A. (1994a). Chloridiki erevna merikon idroviotopon tis Lesvou (Floristic investigation of some vernal pools of Lesvos (E. Aegean, Greece)). Proceedings of the 16th Panhellenic Conference of the Hellenic Society for Biological Sciences (Volos 5-7.5.1994): 2.7-2.9. Athina (in Greek with English abstract).

BAZOS, I. \& YANNITSAROS, A. (1994b). Simvoli sti gnosi tis pteridofitikis chloridas tis Lesvou. Perilipsis 5ou Epistimonikou Sinedriou Ellinikis Votanikis Eterias, Delfi, Oktovrios 1994: 24 (in Greek).

BAZOS, I. \& YANNITSAROS, A. (in press). Rare plants from aquatic and semiaquatic habitats of Lesvos island (East Aegean, Greece). Bocconea.

BERGMEIER, E. \& MATTHÄS, U. (1995). Additions to the flora of W Crete. Willdenowia 25: 81-98. 
BÖHLING, N. (1995). Zeigerwerte der Phanerogamen-Flora von Naxos (Griechenland). Ein Beitrag zur ökologischen Kennzeichnung der mediterranen Pflanzenwelt. Stuttgarter Beitr. Naturk., ser. A, 533: 1-75.

CANDARGY, C. A. (1889). Flore de l'ile de Lesbos. Plantes Sauvages et Cultivées. Zürich: Uster.

CANDARGY, P. C. (1897). Flore de l'île de Lesbos. Bull. Soc. Bot. Fr. 44: 369-373.

CANDARGY, P. C. (1898). Flore de l'île de Lesbos. Bull. Soc. Bot. Fr. 45: 181-192.

CANDARGY, P. C. (1899). La végétation de l'île de Lesbos (Mytilène). Rev. Gen. Botanique 11: 268-280, 310-329.

CARLSTRÖM, A. (1987). A Survey of the Flora and Phytogeography of Rodhos, Simi, Tilos and the Marmaris Peninsula (SE Greece, SW Turkey). Lund: University of Lund.

CHRISTIANSEN, S. G. (1986a). Ophioglossum L. In: STRID, A. (ed.) Mountain Flora of Greece 1: 12-13. Cambridge: Cambridge University Press.

CHRIST I ANSEN, S. G. (1986b). Asplenium L. In: STRID, A. (ed.) Mountain Flora of Greece 1: 16-25. Cambridge: Cambridge University Press.

CHRISTI ANSEN, S. G. (1986c). Dryopteris Adanson In: STRID, A. (ed.) Mountain Flora of Greece 1: 32-35. Cambridge: Cambridge University Press.

CHRISTODOULAKIS, D. (1986). I chlorida ke $i$ vlastisi tis Samou (Die Flora und Vegetation der Insel Samos (Griechenland)). PhD thesis, Patra (in Greek with German summary).

CHRISTODOULAKIS, D. (1996). The flora of Ikaria (Greece, E. Aegean Islands). Phyton (Horn, Austria) 36(1): 63-91.

CONSTANTINIDIS, Th. (1997). I chlorida ke $i$ vlastisi ton oreon Gerania, Pateras ke Kitheron. [The flora and vegetation of the mountains Gerania, Pateras and Kitheron (SE Sterea Ellas, Greece)]. PhD thesis, Athina (in Greek with English summary).

DAVIS, P. H. (ed.) (1965). Flora of Turkey and the East Aegean Islands 1. Edinburgh: Edinburgh University Press.

DEMIRIZ, H., VIANE, R. \& REICHSTEIN, T. (1990). Asplenium obovatum var. protobillotii var. nov. and var. deltoideum var. nov. in Turkey, with remarks on the status of A. billotii. Candollea 45: 241-259.

DIEMAR, S. \& SEBERG, O. (1989). Biographical and bibliographical notes on C. A. and P. C. Candargy. Taxon 38(4): 569-575.

DINTER, I. (1995). Perlen der Ägäis - die Inseln Lesbos und Chios in der Ägäis. Lauffen: privately published.

EDMONDSON, J. R. (1982). Additions to the flora of Lesvos and its offshore islets. Ann. Mus. Goulandris 5: 33-53.

EMBERGER, L. (1955). Une classification biogéographique des climats. Recueil Trav. Lab. Bot. Zool. Univ. Fac. Sci. Montpellier 7: 3-43.

EMBERGER, L. (1959). Orientation actuelle au service de la C.G.V. de la cartographie physiologique appliquée. Bull. Serv. Carte Phytogéogr., ser. B, 4(2).

GRADSTEIN, S. R. \& SMITTENBERG, J. H. (1977). The hydrophilous vegetation of western Crete. Vegetatio 34: 65-86.

GREUTER, W. (1973). Additions to the flora of Crete, 1938-1972. Ann. Mus. Goulandris 1: 15-83.

GREUTER, W. (1974). Floristic report on the Cretan area. Mem. Soc. Brot. 24(1): 131-171.

GREUTER, W. (1979). The flora and phytogeography of Kastellorizo (Dhodhekanisos, Greece). 1. An annotated catalogue of the vascular plant taxa. Willdenowia 8: 531-611.

GREUTER, W. \& RECHINGER, K. H. fil. (1967). Flora der Insel Kythera, gleichzeitig Beginn einer nomenklatorischen Überprüfung der griechischen Gefässpflanzenarten. Boissiera 13: 1-206. 
GREUTER, W., BURDET, H. M. \& LONG, G. (eds) (1984). Med-Checklist 1. Genève: Conservatoire et Jardin botaniques de la Ville de Genève.

GUTER M A N N, W. (1995). Catalogus Abbreviatus Plantarum Vascularium ex Ionii Insulis Cognitarum. Vindobonae.

HALÁCSY, E. de (1904). Conspectus Florae Graecae 3. Lipsiae: Sumptibus Guilelmi Engelmann.

HANSEN, A. (1982), Additions to and Notes on the Flora of Corfu and Vidos (Ionian Islands, Greece). Bot. Chron. 2(1): 18-49.

HANSEN, A. \& NIELSEN, H. (1993). Contribution to the flora of Lesvos (Mitilini), Greece. Willdenowia 23: 143-156.

HOFMANN, U. (1968). Untersuchungen an Flora und Vegetation der Ionischen Insel Levkas. Viert. Naturf. Ges. Zürich 113(3): 209-256.

JAGEL, A. (1992). Zur Flora und Vegetation der Insel Elafonisos (Lakonien, Griechenland). Diplomarbeit, Ruhr-Universität Bochum.

JALAS, J. \& SUOMINEN, J. (1972). Atlas Florae Europaeae 1. Pteridophyta (Psilotaceae to Azollaceae). Helsinki: The Committee for Mapping the Flora of Europe and Societas Biologica Fennica Vanamo.

JER MY, A. C. (1965). Isoetes L. In: Davis, P. H. (ed.) Flora of Turkey and the East Aegean Islands 1: 37-38. Edinburgh: Edinburgh University Press.

LAVR ENTIA DIS, G. (1956). Erevne epi tis idroviou ke eloviou chloridos ton emvriofiton tis ellinikis Makedonias (On the hydrophytes of Greek Macedonia). $\mathrm{PhD}$ thesis, Thessaloniki (in Greek with English summary).

MAVROMATIS, G. (1974). Paratirisis epi tis ikologias tis dasikis vlastiseos tis nisou Lesvou (Some observations on the ecology of the forest vegetation of Lesvos island). To Dasos 63/64: 42-47 (in Greek with English summary).

NATIONAL INSTITUTE OF GEOLOGICAL AND MINING RESEARCH (NIGMR) (1972-1975). Geological Map of Greece. Lesbos Island. $1: 50000$ (five sheets). Athine: NIGMR.

PAPATSOU, S. H. (1975). I chloris ke $i$ vlastisis tis $n$. Nisirou ke ton peri avtin nisidon (Flora and vegetation of the island Nisyros and the surrounding islets). PhD thesis, Patre (in Greek with English summary).

PAVLIDIS, G. A. (1976). I chloris ke i vlastisis tis chersonisou Sithonias Chalkidikis [On the flora and vegetation of the Sithonia peninsula (Chalkidiki, Greece)]. PhD thesis, Thessaloniki (in Greek with English summary).

PHITOS, D. (1960). Fitogeografiki erevna tis Kendrikis Evvias (Pflanzengeographische Untersuchung der zentrale Euboea). PhD thesis, Athine (in Greek with German summary).

PHITOS, D. (1967). Florula Sporadum. Phyton (Austria) 12(1-4): 102-149.

PHITOS, D. \& DAMBOLDT, J. (1985). I chlorida tis nisou Kefallinias (Die Flora der Insel Kefallinia (Griechenland)). Bot. Chron. 5: 1-204.

PHITOS, D., STRID, A., SNOGERUP, S. \& GREUTER, W. (eds) (1995). The Red Data Book of Rare and Threatened Plants of Greece. Athens: WWF.

PICHI SERMOLLI, R. E. G. (1979). A survey of the pteridological flora of the Mediterranean region. Webbia 34(1): 175-242.

RASBACH, H., RASBACH, K., REICHSTEIN, T., VIANE, R. L. L. \& BENNERT, H. W. (1990). Asplenium obovatum subsp. obovatum var, protobillotii and its hybrid with Asplenium obovatum subsp. lanceolatum in Spain (Aspleniaceae, Pteridophyta). Bot. Helv. 100: 3-16.

RAUH, W. (1949). Klimatologie und Vegetationsverhältnisse der Athos-Halbinsel und der ostägäischen Inseln Lemnos, Evstratios, Mytiline und Chios. Sitzugsber. Heidelberger Akad. Wiss., Math-Nat. Kl. 12: 511-615. 
RAUS, Th. (1996). Flora von Paros und Antiparos (Kykladen, Griechenland). Ann. Naturhist. Mus. Wien 98B [Suppl.]: 237-278.

RECHINGER, K. H. fil. (1943). Flora Aegaea. Akad. Wiss. Wien, Math-Naturwiss. Kl., Denkschr. 105(1).

RECHINGER, K. H. (1949). Florae Aegaeae Supplementum. Phyton 1: 194-228.

RECHINGER, K. H. fil. (1961). Die Flora von Euboea. Bot. Jahrb. Syst. 80: 294-465.

RUNEMARK, H., SNOGERUP, S. \& NORDESTAM, B. (1960). Studies in the

Aegean Flora. I. Floristic Notes. Bot. Not. 113: 421-450.

SAUVAGE, C. (1961). Recherches géobotaniques sur les subéraies marocaines. Trav. Inst. Sci. Chérifien Sér. Bot. 21. Rabat.

SNOGER UP, S. (1995). Pilularia minuta Durieu ex A. Braun. In: PHITOS, D., STRID, A., SNOGERUP, S. \& GREUTER, W. (eds) The Red Data Book of Rare and

Threatened Plants of Greece, pp. 414-415. Athens: WWF.

SNOGERUP, S. \& SNOGERUP, B. (1991). Flora and vegetation of the island of Agios Evstratios, Greece. Bot. Chron. 10: 527-546.

SNOGERUP, S. \& SNOGERUP, B. (1993). Additions to the flora of Samos, Greece. Fl. Medit. 3: 211-222.

SNOGERUP, S., BOTHMER, R, von \& GUSTAFSSON, M. (1980). Floristic report from the island of Psathura (Greece). Bot. Not. 133: 145-148.

STEFANI, C. de, FORSYTH MAJOR, C. J. \& BAR BEY, W. (1891). Samos, étude géologique, paléontologique et botanique. Lausanne: Georges Bridel \& $\mathrm{C}^{\mathrm{ie}}$.

STEPHANIDES, Th. (1948). The aquatic and semi-aquatic flora of the Ionian islands. Prakt. Ellin. Idroviol. Inst. 2: 187-201.

STRID, A. (ed.) (1986). Mountain Flora of Greece 1. Cambridge: Cambridge University Press.

STRID, A. \& FRANZÉN, R. (1982). New floristic records from the mountains of northern Greece. Willdenowia 12: 9-28.

STRID, A. \& TAN, K. (eds) (1997). Flora Hellenica 1. Königstein: Koeltz Scientific Books.

TURLAND, N. J., CHILTON, L. \& PRESS, J. R. (1993). Flora of the Cretan Area. Annotated Checklist \& Atlas. London: HMSO.

TUTIN, T. G., BURGES, N. A., CHATER, A. O. et al. (eds.) (1993). Flora Europaea 1. 2nd edition. Cambridge: Cambridge University Press.

VIANE, R., JERMY, A. C. \& LOVIS, J. D. (1993). Asplenium L. In: TUTIN, T. G. et al. (eds), Flora Europaea 1: 18-23. 2nd edition. Cambridge: Cambridge University Press.

VIANE, R., RASBACH, H., RASBACH, K. \& REICHSTEIN, T. (1996). Observations on some ferns of Poros and adjacent parts of the Peloponnesus (Greece). Bocconea 5: 279-300.

VOLIOTIS, D. (1979). Flora und Vegetation des Voras-Gebirges (Flora and vegetation of the Voras mountains). Sci. Annals, Fac. Phys. \& Mathem., Univ. Thessaloniki 19: 189-278.

WETTSTEIN, R. von (1886). Isoetes Heldreichii. Verh. Zool.-Bot. Ges. Wien 36: $239-240$.

YANNITSAROS, A. (1977). Contributions to the vernacular names of the Greek plants II. Vernacular names of plants from the island of Lesvos. Biol. Gallo-Hellen. 6(2): $311-316$.

YANNITSAROS, A. (1979). Prokatarktiki meleti gia tin prostasia tis chloridas ke vlastisis tis Lesvou (A preliminary study for the protection of the flora and vegetation of the island of Lesvos). I Fisis 18: 15-25, 44-46 (in Greek with English summary). 
YANNITSAROS, A. (1998). Additions to the flora of Kithira (Greece) I. Willdenowia 28: 77-94.

ZAFFRAN, J. (1990). Contribution à la flore et à la végétation de la Crète. Marseille: Université de Provence.

ZAGANIAR IS, D. (1940). Herbarium macedonicum. Tertium et quartum mille. Epist. Epet. Schol. Fis. Math. Epist. Panepist. Thessalonikis 6: 38-139.

ZIMMER, B. (1991). Remarks on the Greek cheilanthoid ferns. Bot. Chron. 10: 221-237.

Received 3 February 1999; accepted with revision 22 June 1999 